\title{
The climate in south-east Moravia, Czech Republic, 1803-1830, based on daily weather records kept by the Reverend Šimon Hausner
}

\author{
Rudolf Brázdil $^{1,2}$, Hubert Valášek ${ }^{1,3, \dagger}$, Kateřina Chromá ${ }^{2}$, Lukáš Dolák ${ }^{1,2}$, Ladislava Řezníčkováa ${ }^{1,2}$, \\ Monika Bělínová ${ }^{2}$, Adam Valík ${ }^{1,4}$, and Pavel Zahradníček ${ }^{2,4}$ \\ ${ }^{1}$ Institute of Geography, Masaryk University, Brno, Czech Republic \\ ${ }^{2}$ Global Change Research Institute, Czech Academy of Sciences, Brno, Czech Republic \\ ${ }^{3}$ Moravian Land Archives, Brno, Czech Republic \\ ${ }^{4}$ Czech Hydrometeorological Institute, Brno, Czech Republic \\ $\dagger$ deceased
}

Correspondence: Rudolf Brázdil (brazdil@sci.muni.cz)

Received: 4 March 2019 - Discussion started: 8 March 2019

Revised: 7 June 2019 - Accepted: 15 June 2019 - Published: 2 July 2019

\begin{abstract}
Weather diaries constitute an important source of data for historical climatology, employed in the analysis of weather patterns for both the pre-instrumental and the early instrumental periods. Among the many weather diaries that exist in Europe, the daily records kept by the Reverend Šimon Hausner from Buchlovice in south-east Moravia (Czech Republic), covering the 1803-1831 period, are particularly useful. His qualitative daily weather descriptions enable the construction of series for temperature, precipitation, cloudiness, wind, and other weather phenomena (particularly thunderstorms and fogs), supplemented by a number of phenological and agricultural work records. His data related to temperature and precipitation patterns were quantified into a series of weighted temperature and precipitation indices on 7degree scales, which were subsequently compared with standard meteorological observations from the secular meteorological station in Brno. This comparison indicates that Hausner's observations are highly reliable and confirms the importance of his data for a better understanding of the variability in the regional climate in the period of early instrumental measurements in Moravia. At the same time, it reveals the importance of weather-related documentary data in the overlap period with instrumental meteorological observations.
\end{abstract}

\section{Introduction}

Recent historical climatology uses a very broad range of documentary evidence, including information about weather and related phenomena, for reconstructions of past climate variability (Brázdil et al., 2005a, 2010; White et al., 2018). Among such sources, visual daily weather observations are of particular importance, often appearing in the form of weather diaries (for the use of private diaries, see the overview paper by Adamson, 2015). Weather diaries usually contain qualitative descriptions of daily weather and, at varying degrees of detail, they also describe certain meteorological, hydrological, and phenological events and their impacts.

Although weather diaries occur nearly all over the world (e.g. see Glaser et al., 1991; Druckenbrod et al., 2003; Hirano and Mikami, 2008; Mikami, 2008; Zhang et al., 2013; Adamson and Nash, 2014; Lorrey and Chappell, 2016), Europe is a particularly rich region for them, spanning a period of almost 8 centuries. The first known daily weather records, for 1269-1270, appeared in England among a volume of papers by Roger Bacon (Long, 1974), followed by observations made by the Reverend William Merle in Lincolnshire from the years 1337 to 1344 (Lawrence, 1972). Further European weather diaries were reported in a paper by Pfister et al. (1999), with special reference to the 16th century. Some of these have been analysed in great detail, e.g. in the Czech Lands (Brázdil and Kotyza, 1995, 1996) and in 
Poland (Bokwa et al., 2001; Limanówka, 2001). Other authors continued the story for the late 16th and early 17 th centuries (Lenke, 1968; Metzger and Tabeaud, 2017). Still more such diaries then appeared in the 17th century (e.g. Chernavskaya, 1994; Bokwa et al., 2001; Brázdil and Kiss, 2001; Nowosad et al., 2007; Przybylak and Marciniak, 2010; Zwitter, 2013; Domínguez-Castro et al., 2015), as well as in the 18th century (e.g. Chernavskaya, 1994; Brázdil et al., 2008b; Raicich, 2008; Sanderson, 2018; Filipiak et al., 2019), at which point they start to occur concurrently with instrumental observations and take on some of the character of early instrumental meteorological observations; they have even been used to create long-term series of meteorological variables (e.g. Woodworth, 2006). They lost little importance even in the period of instrumental measurements when they added important supplementary data to measurements taken at meteorological stations (e.g. Lee and MacKenzie, 2010).

In what has become the Czech Republic in recent years, the earliest daily weather records appeared in south-eastern Moravia, where the Moravian nobleman Jan of Kunovice included daily weather entries into Stoeffler's ephemerides for the years 1533-1545 (Brázdil and Kotyza, 1996). Several other authors followed during the 16th century (for a summary overview, see Brázdil et al., 2013a). Worthy of special mention are the systematic daily weather records kept in the diaries of the Premonstratensian order in the Hradisko monastery (Olomouc) and the Svatý Kopeček priory, spanning the 1693-1783 period with meteorological data covering only 52 years. However, their records for the remaining years have not survived (Brázdil et al., 2008a, 2011). Fortunately, the 1780s are covered by systematic daily weather records kept by Karel Bernard Hein, a priest in Hodonice, south-western Moravia (Brázdil et al., 2003), followed by several others that describe only a few years (e.g. Brázdil et al., 2002a, 2007b). The fact that the later examples overlapped with early instrumental observations means that they made important contributions to knowledge of climate variability at a time when instrumental measurements were running at only a few stations.

Moreover, if such diaries were accompanied by individual instrumental data, they may form a basis for the creation of long-term series, linking them to subsequent standard meteorological observations. This occurred in Brno in South Moravian Region, where temperature series start in May 1799 and precipitation series in January 1803 (Brázdil et al., 2005b, 2006). Surprisingly, weather diaries supplemented by measurements of certain meteorological variables also appear as very useful sources of meteorological data far later, as is made evident by the example of the meteorological records kept by Alexander Zawadzki in Brno in 1861-1867 (Brázdil et al., 2013b) and Josef Lukotka in Vsetín in 1903-1923 (Brázdil et al., 2014).

The weather diary kept by Šimon Hausner, a priest in Buchlovice, south-east Moravia (Czech Republic), covering the years $1803-1831$, is one such newly discovered weather diary, overlapping with the period of early instrumental meteorological observations. The aim of this study is a comprehensive analysis of these long-term observations, which add an emphasis on the importance of weather diaries to a basic analysis of observed data for the better understanding of regional climatic variability and anomalies, as well as their impacts. Section 2 presents a basic account of Šimon Hausner and his diary, while Sect. 3 puts Hausner's observations into temporal context. After a description of methods used (Sect. 4), the results of statistical analysis of his observations for individual meteorological elements and phenomena are presented in Sect. 5. Uncertainty in Hausner's records and comparison of the results obtained with meteorological observations from the secular Brno meteorological station are discussed in Sect. 6. The final section contains some concluding remarks.

\section{2 Šimon Hausner and his weather diary}

Šimon Hausner, the author of the weather diary under discussion, was born on 27 October 1756 at Odry in northern Moravia to a German Catholic family (for the locations of places mentioned herein, see Fig. 1). He was called to a priestly career and on 23 September 1780 was ordained as a priest. Until 1784 he was a chaplain, probably in the Buchlovice parish. In that year he left for Žeravice, where he served as a local chaplain [lokalista] until 1796. On 6 June 1796, the owner of Buchlov domain, Anežka Eleonora Petřvaldská, elevated him to the position of parish priest in Buchlovice. He also served as a priest for the parishioners of four nearby villages, with whom he communicated in the Czech language. From 1800 onwards, when the Buchlov domain passed into the hands of the Berchtold family, Hausner's relationship with this family deteriorated. He prepared a Latin chronicle called Memorabilia Hausneriana but this was lost at the end of the 19th century. He made records of inscriptions and recorded interior descriptions of the surrounding churches and chapels, most of them no longer standing. He devoted particular attention to the baroque church of Saint Martin and nearby manse in Buchlovice. When the tower of this church was destroyed by a lightning strike on 4 August 1806 he gave financial support to the renovation of the church. A flash flood did heavy damage to the area on 12 June 1825 and, in a similar spirit, he organized financial collections in surrounding villages to help people affected by the disaster. He died of severe pneumonia on 26 January 1831 at Buchlovice (Žižlavský, 1998; Hrdý et al., 2005; archival sources AS1 and AS2).

Hausner's weather observations, written in German, are part of a hand-made book in the keeping of the Moravian Land Archives in Brno (AS3). The German title appears on the flyleaf, written in a hand other than Hausner's: Tägliche Witterungs-Beobachtungen des Buchlowitzer Pfarrer Simon Hausner von Jahren 1803 bis 1831 excl. ["Daily weather ob- 


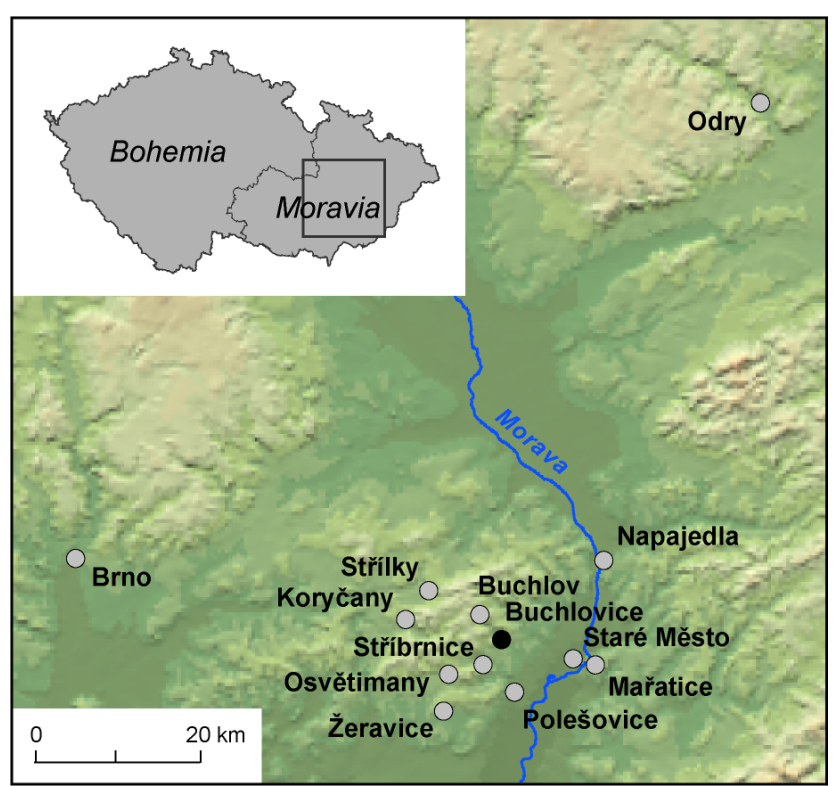

Figure 1. Locations of places within the Czech Republic referred to in this article.

servations from the Reverend Šimon Hausner of Buchlovice from 1803 to 1831"]. The first weather record appears for 1 January 1803 and the last for 15 January 1831 (Fig. 2), very shortly before he passed away. The author described the weather day by day. Some of the records are quite short; for example, for 3-5 February 1805 (AS3, p. 34): "3 [February]. Overcast all day. 4 [February]. Same, both days glaze ice. On the 5th [the night of 4/5 February] west wind and snowfall. 5 [February]. Again thawing." Other entries go into more detail, even describing the weather at various times of the day; for 20 July 1828 (AS3, p. 851) his notes read: "a pale sunrise, nice sunshine, very hot sunshine from noon to 4 p.m., at 5 p.m. became a little more agreeably cool. In the evening at 10 p.m., heavy rain, soon followed by a very heavy downpour together with a windstorm that continued until the first hour after midnight. S.V.V. [south-west wind]".

The weather records for the majority of months end with a summarizing evaluation of the given month. For example, for March 1808, he wrote (AS3, p. 109): "Very hard frosts during the whole of March, which were stronger [as those] in December and January. The soil was frozen to a depth of two feet [ca. $63 \mathrm{~cm}$ ], dust when walking and riding, almost as if it were in summer; no snow at all, fields without cover, [exposed to] cold winds, severe frosts at night, nice sunshine during the day". On other occasions, he repeated the weather for certain days or mentioned events previously not reported for individual days; for example, the entry for May 1825 reads (AS3, p. 736): "The first four days [of May] were cold enough, from 4th to 7 th very scorching sunshine, from 7th to 14th gloomy and overcast, [from 14th] on 15th heavy frost that damaged vineyards, from 15 th to the end [of May] variable, weather very cold; it was very pleasant in a well-heated room. Several showers that only damped the dust down, none abundant."

At the end of every year he prepared a weather summary for the whole year; for example the entry for 1803 reads (AS3, p. 13): "The winter of this year was very cold, with severe frosts for six weeks [and] a large quantity of snow fell; the spring was cold and wet, it rained nearly all summer, making it cold and wet. The autumn was cold and rainy but mid-September was warmer." This account of the weather was usually followed by information concerning the growth of crops and harvests; for example, the entry for the year 1811 reads (AS3, pp. 210-212): "All of September was dry for the straw and the vintage came as early as 17th [September], due to periods of great heat. All kinds of cereals, legumes, cabbage and potatoes did not yield. [...] Very small [yield] of cherries, [which] were wormy and rotted. Also only a few apples on the trees [...] Very few pears $[\ldots]$ Few apricots [...] A lot of plums in some places [...] This year's wine was very good in quantity and even better in quality. [...] Autumn sowing went well. Fields were cultivated in dust [... ]." Hausner's annual summaries are often accompanied by further information, very often reporting prices of grain, fruit and vegetables, etc.

\section{The temporal context of Hausner's observations}

Part of the unique character of Hausner's observations arises out of their development of meteorological observations in Moravia and Silesia (Silesia here understood as its Moravian section). The earliest surviving instrumental measurements of several meteorological elements, provided by František Alois Mag of Magg, a physician in Telč, appear in his second diary, in entries between 7 May 1771 and 9 March 1775. Although his diary contains references to his first and third diaries, i.e. Mag was observing before 1771 and after 1775, these have not yet come to light (Brázdil et al., 2002b). Further systematic daily weather records, but without instrumental measurements, were provided by Karel Bernard Hein, a priest in Hodonice, covering the period between 1 February 1780 and 5 October 1789 (Brázdil et al., 2003). Some indications of meteorological conditions (pressure, temperature, moisture, evaporation, wind) for the 1790-1794 period, kept by Josef Gaar, a professor at the Olomouc lyceum, follow from tables and figures included in the description of the climate of Moravia entitled Anleitung zum Kenntnis des Erbmarkgrafthumbs Mähren ["An Introduction to Knowledge of the Moravia Margraviate"] by Kryštof Passy, 1797 (Brázdil and Valášek, 2001). Continuous meteorological observations began in Brno in May 1799, provided by Ferdinand Knittelmayer, a retired military captain. From 1 January 1803 , these records were supplemented by those of Zacharias Melzer, a land accountant who took regular precipitation measurements (Brázdil et al., 2005b, 2006). Both 
(a)

(b)

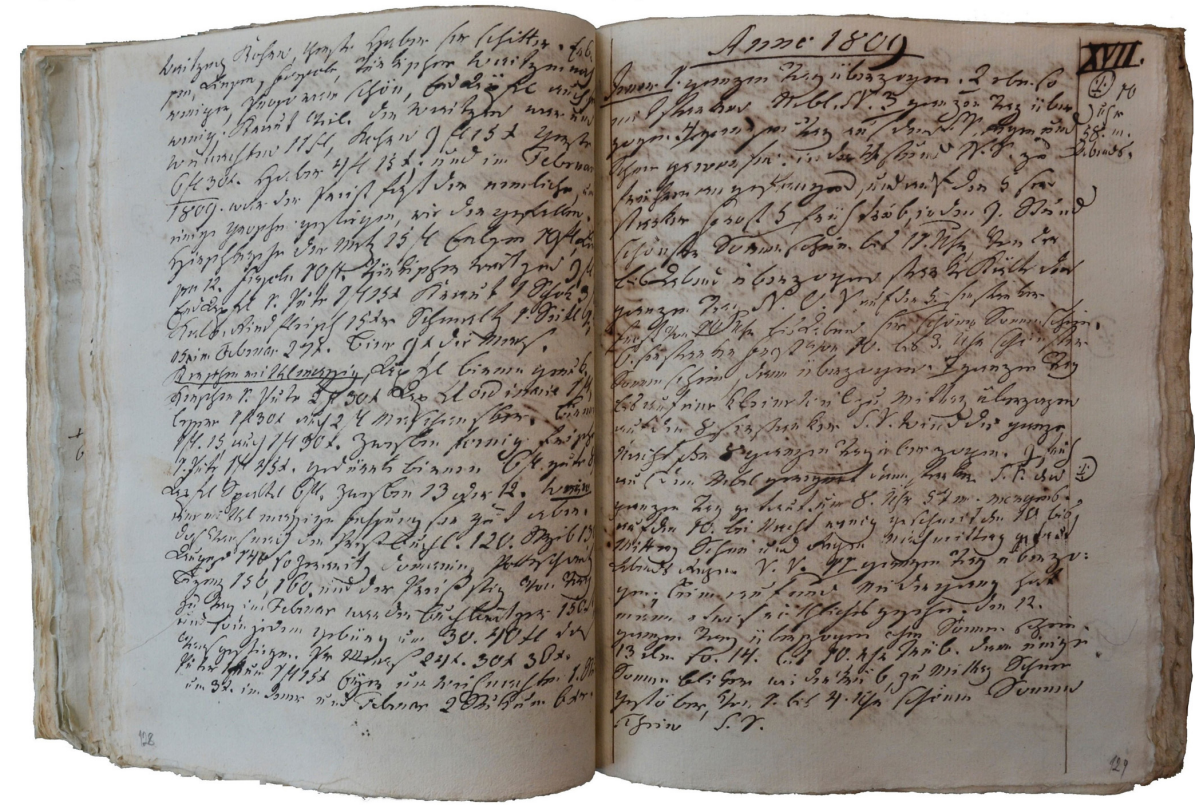

Figure 2. Example of pages from Hausner's weather diary, with records from the end of 1808 (a) and the beginning of 1809 (b) (AS3).

measurements enabled the compilation of secular homogenized Brno temperature and precipitation series, comparable to the already-known Prague-Klementinum measurements in Bohemia (Pejml, 1975; Brázdil et al., 2012a). The creation of "economic societies" in the Austrian empire, intended to support the general economic development of the country, was of key importance to the further development of instrumental meteorological observation in Moravia and Silesia through the efforts of the Imperial-Royal Moravian-Silesian Economic Society, part of this project. This society organized a network of meteorological stations (Fig. 3), collating the results of their observations (AS5). These are usually, however, relatively short and entries for many months are missing. Meteorological observations from Jihlava - where Andreas Sterly, a town councillor, kept daily observations in the 1816-1840 (1844) period - are an exemplary exception among these stations (Brázdil et al., 2007a). This overview demonstrates the high importance of Hausner's observations, bridging a spatial gap on the one hand and covering a very long period with otherwise only few observations for Moravia on the other.

\section{Methods}

\subsection{Interpretation of Hausner's weather records}

Hausner deployed a wide vocabulary to describe the weather and its changes during the day. Although his records often cover an entire day, his mode of specification often enables attribution of the phenomena described to the morning, afternoon, evening, and nighttime hours. To simplify this for the purposes of analysis, the night and morning hours have generally been taken together, as well as afternoon and evening hours (using noon and midnight as the dividing times). Hausner's terminology permitted analysis of the following weather patterns and phenomena in the fashion described below:

\section{i. temperature patterns}

Hausner used a wide range of words for description of temperature conditions. Warm weather was characterized as warm [warm], modified by rather [ziemlich] or very [sehr], hot [heiß, heißer Tag], or sultry [schwül]. Warming in the winter months with snowmelt was described as Tauwetter or getaut; mud [Koth] or muddy $[k o t h i g]$ often followed. For cold weather he used the terms cold [kühl, kalt, Kälte], very cold [sehr kalt], "piercing" cold [durchdringend kalt], or horribly cold [grimmige Kälte]. Frost [Frost, gefroren] was modified as light [klein], negligible [unbedeutend], bearable [leidlich], heavy [stark], or very heavy [sehr stark]. Hoarfrost [Reif] was reported separately. Hausner also indicated cold weather indirectly by remarks such as "a fur coat and a heated room were very good" [der Peltz und geheitzte Zimmer waren sehr gut]. Particularly in the winter months, the weather was also described as mild [lind, lindes Witterung] or very mild [sehr lindes Witterung]. An indication of temperature patterns also appeared in wind descriptions, characterized as warm [warm] or very warm [sehr warm] wind, and cold [kalt] or very cold [sehr kalt/kühl] wind. 


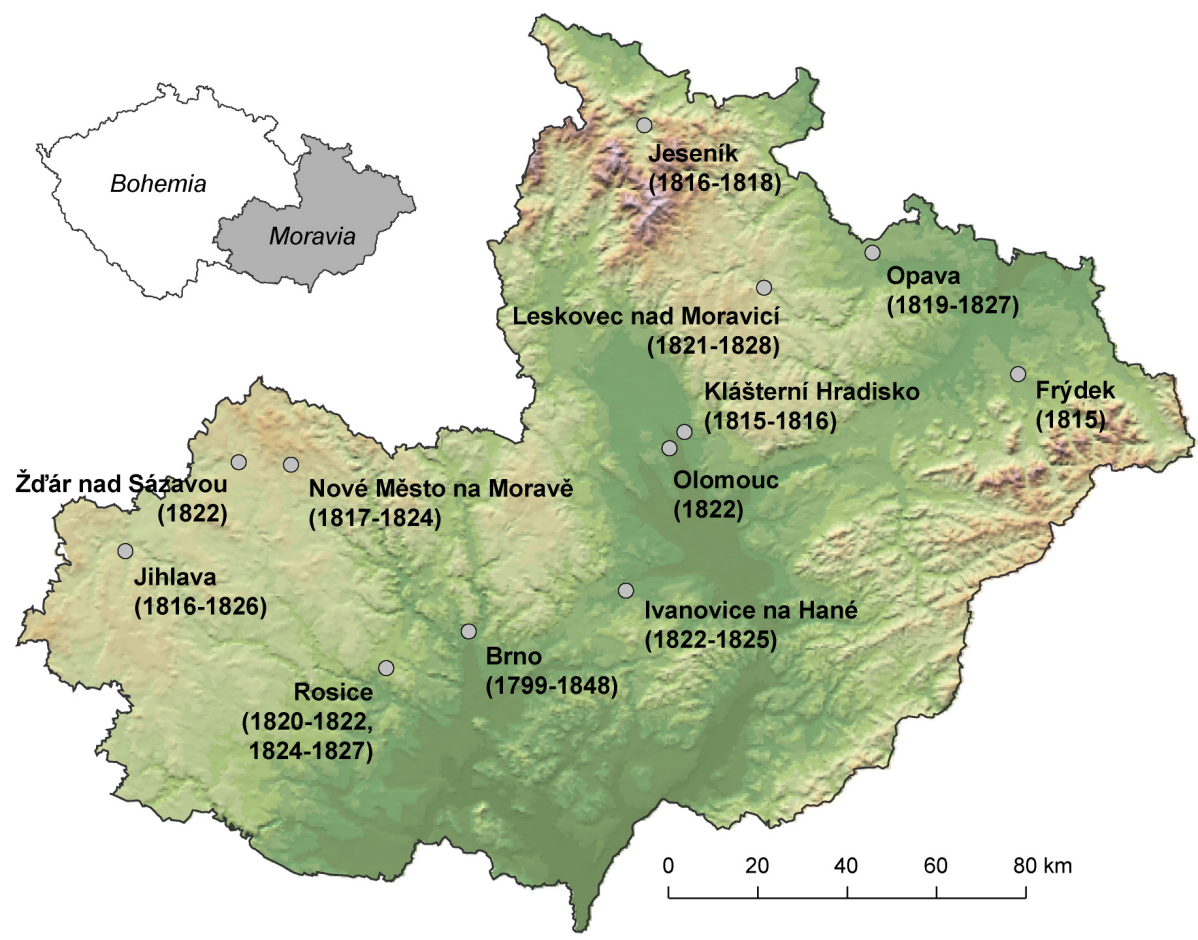

Figure 3. Network of meteorological stations in Moravia and Silesia as organized by the Imperial-Royal Moravian-Silesian Economic Society (years indicate available meteorological observations preserved in AS5).

\section{ii. precipitation patterns}

Hausner characterized individual types of precipitation as drizzle [nieseln, wie aus dem Nebel geregnet]; rain [Regen, regnerisch, geregnet], modified as "fine" [klein], light [lind], negligible [unbedeutend], weak [Regen, der den Staub gelöscht], average [mittelmäßig], heavy [ausgiebig], very heavy [sehr stark], continuous [beständig], frequent [öfters], showers [Streifregen], downpour, cloudburst, or torrential rain [Platzregen, Gussregen, Guss, gegossen]; snow [Schnee, geschneit], modified as light [wenig] or heavy [stark]; and ice pellets [Graupen] or hail [Hagel, Schlossen], sometimes described as small [klein]; black ice was Glatteis. Even the depth of snow was specified (e.g. Schnee auf 2 Zoll [ca. $5.3 \mathrm{~cm}$ ] gefallen). Dry weather was indicated by the term dry [trocken], modified as very [sehr] or extraordinary [außerordentlich]. A month without rain was Monat ohne Regen.

iii. sunshine and cloudiness

Hausner often started his daily weather records with the character of the sunrise [Sonnenaufgang], modified as gloomy [trüb], pale [blass], weak [schwach], nice [schön], or nice red sky [schöne Morgenröthe]. Sunshine [Sonnenschein] was specified as nice [schön], beautiful [prächtig], very pleasant [sehr angenehm], weak [schwach], very weak [sehr schwach], partial [teilweise], broken [gebrochen], rare [selten], intermit- tent [abwechselnd], warm [warm], and very hot [sehr heiß]. He often specified the duration of sunshine during a day by the hours at which it began and ended; short, variable sunshine was identified as Sonnenblicke. A "nice day" [schöner Tag] was opposite to a "sad day" [trauriger Tag]. Days without sunshine were described as overcast [überzogen, trüb].

iv. wind patterns

Information about the wind [Wind] appears in the diary with some degree of regularity. Broadly, wind intensity (force) was characterized as average [mittelmäßig], strong [stark], very windy [sehr windig], very strong [sehr stark, sehr heftig], "awful" [fürchterlich], and extraordinary [außerordentlich]. Windstorm [Sturmwind] was worthy of special mention, as were blizzard [Schneegestöber] and whirlwind [Wirbelwind] Only seldom did Hausner record calm [windstill]. Wind directions were described on an 8-degree scale, usually written in the form of abbreviations.

v. meteorological phenomena

Hausner recorded thunderstorm phenomena systematically, discriminating between their occurrence as thunderstorm [Donnerwetter, Wetter] local to Buchlovice and distant thunderstorms [Wetterlichten, geblitzt, gedonnert] at a greater distance. He also reported on places other than Buchlovice, particularly if some dam- 
age had occurred. Bad visibility was characterized as foggy [neblich] or directly as fog [Nebel], modified as light [klein] or dense [stark]. For especially dense fog he reported on the number of places at which it was possible to see with respect to dominant objects in the immediate surroundings (e.g. the local chateau, statues of the saints).

vi. phenological data

As a meticulous observer, Hausner also recorded certain phenophases of crops and fruit trees, including corresponding agricultural work. He gave close attention to the dates of spring and autumn sowing, the beginning and end of blossom on fruit trees, the progress of cereals and grapevines, the beginning of harvest for individual cereals, and the start of the vintage.

\subsection{Methods of analysis}

From a statistical point of view, it is important that only relatively few daily records are absent from Hausner's diary (Fig. 4). A total of $80 \mathrm{~d}$ are missing (i.e. around $3 \mathrm{~d}$ per year), tending towards the years 1803-1813 (66 d) with a maximum in 1810 ( $11 \mathrm{~d}$, i.e. $3.0 \%$ of days in this year), followed by 1805 ( 9 d, i.e. $2.5 \%$ ) and 1809 (8d, i.e. $2.2 \%$ ) (Fig. 4a). Only $14 \mathrm{~d}$ of missed observations occurred in 1814-1830 (with 0, 1 , or 2 missing days per year, i.e. from $0 \%$ to $0.6 \%$ ). In terms of annual distribution, the maximum of 10 missing days in February make up only $1.3 \%$ of all February days, while 3 missing days in September correspond to $0.4 \%$ of all September days (Fig. 4b). With the exception of 9 missing days in August and October (1.0\%), all the remaining months missed fewer than $1 \%$ of their days. The days with missing observations may have a minor effect on the results for frequencies of days with various climatic variables. On the other hand, not all possible meteorological elements or phenomena are covered systematically in the daily records, a factor that may then be reflected in incomplete frequencies of days with these characteristics or phenomena.

With respect to the character of Hausner's daily weather records, it proved impossible to apply some of the newer quantitative approaches to interpretation of monthly temperature and precipitation indices (e.g. see FernándezFernández et al., 2017; Filipiak et al., 2019). This led to our use of a version of the approach by Pfister (1992), broadly applied, combining different kinds of sources and their expert evaluation. Information related to temperature patterns was used to interpret monthly temperature indices by expression on a 7 -degree scale: -3 extremely cold, -2 very cold, -1 cold, 0 normal, 1 warm, 2 very warm, and 3 extremely warm (Pfister, 1992). Interpretation of temperature indices took into account the broad scale of indicators derived from Hausner's records: the monthly frequencies of cold days (severe frost, frost, cold, very cold) and warm days (warm, very warm, hot, very hot, mild), warm and cold winds, monthly summary reports, early and late beginnings of certain phenophases and agricultural work, and also, to some extent, cloudiness (e.g. clear and overcast days) and precipitation (state of precipitation, monthly temperatureprecipitation relationships). The interpretation herein was realized in the following iterations:

i. Pfister (1992) recommended attribution of regularly distributed 7-degree indices to a dataset ordered from the lowest to the highest values: index -3 was employed for $8.3 \%$ of the total, the lowest values; -2 for $16.6 \%$ for the following values, and so onwards with values $16.6 \%$ for each of the subsequent indices $(-1,0,1,2)$ up to $8.3 \%$ for the highest values, attributed to index 3 . This approach was applied separately to the monthly frequencies of cold days and warm days in 1803-1830, which enabled the attribution of an index to each of the months. When indexing the months of the winter half year, rather cold days were considered; in the months of the summer half year, rather warm days were considered.

ii. Monthly indices from point (i) were further evaluated in terms of the structure of cold and warm days, with particular respect to their intensity, based on which corresponding month might be moved to a neighbouring category. For example, a higher proportion of hot or very hot days constituted a reason for movement to a warmer category (e.g. from index 1 to index 2), and similarly a higher proportion of weak frosts or cold days compared to severe frosts and very cold days (e.g. from index -2 to index -1 ). Indications of warm and cold winds as expressions of the character of air advection were also considered.

iii. All indices from iteration (ii) were further considered with respect to monthly temperature summaries and earlier/later onset of phenophases, indicating cooler or warmer patterns in preceding months. Further, information about cloudiness was used as an additional parameter (days with higher sunshine duration being warmer compared to cloudy days). The occurrence of snowfall or snow cover also indicated cooler patterns. The relationships between warm/dry and cold/wet months were also considered for months of the summer half year. All these factors could again lead to some months being shifted to a neighbouring category.

The indices fixed after the third iteration were then considered the final version of weighted monthly temperature indices.

Precipitation indices were interpreted in a similar fashion: -3 extremely dry, -2 very dry, -1 dry, 0 normal, 1 wet, 2 very wet, and 3 extremely wet (Pfister, 1992). The interpretation of monthly precipitation indices was again based on a number of indicators in Hausner's records: monthly frequencies of precipitation days, with particular reference to type 


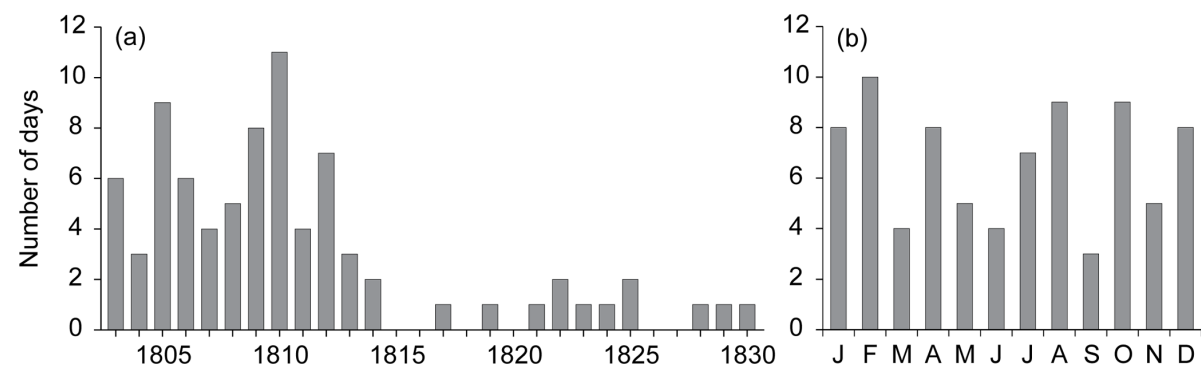

Figure 4. Days missing from daily weather records kept by Šimon Hausner at Buchlovice during 1803-1830 (a) and their annual variation (b)

of precipitation (e.g. snow, drizzle, rain, snow with rain), to precipitation intensity and duration of precipitation spells (as specified in daily records) and to summary monthly reports as well as other indications of wet or dry patterns (e.g. effects on agricultural crops or work in the fields). This interpretation included three iterations:

i. The numbers of monthly precipitation days of the given months in 1803-1830 (28 years) were ordered from lowest to the highest. Following the percentage distribution by Pfister (1992) presented above, corresponding 7 -degree indices from -3 to 3 were formally added to individual months.

ii. Based on additionally reported type, intensity, and duration of precipitation, the corresponding months remained at their already-defined degree from point (i) or were moved to a neighbouring degree. For example, more days with drizzle, or short or light precipitation were favourable to a shift towards a drier index (e.g. from index 2 to index 1), or days with the all-day rain or heavy precipitation during thunderstorms might favour an opposite attribution to a wetter index (e.g. from index -1 to index 0$)$.

iii. All indices from point (ii) were further evaluated from the point of view of summary information concerning the character of precipitation within given months, or in the light of any other precipitation-sensitive information. As in the previous iteration (ii), some months could be moved to an adjacent degree.

After these three iterations, the corresponding monthly precipitation indices were considered final.

Seasonal temperature and precipitation indices were then calculated as the sums of indices of three consecutive months (e.g. June, July, and August for summer). Annual indices were calculated in a similar fashion (Fig. 5). Hausner's daily weather records also provided interpretations of annual numbers of precipitation days (with division into those with solid, mixed, or liquid precipitation), cloudiness, strong winds, periods of fog, and thunderstorms (Figs. 6-8). Further, they enabled the creation of annual series of some phenophases and agricultural work, presented herein as graphs and box plots (Fig. 9).

Temperature and precipitation series for the town of Brno, homogenized at the position of the Brno airport meteorological station $-\varphi=49^{\circ} 09^{\prime} 11^{\prime \prime} \mathrm{N}, \lambda=16^{\circ} 41^{\prime} 20^{\prime \prime} \mathrm{E}, \quad H=$ $241 \mathrm{~m}$ a.s.l. (above sea level; Brázdil et al., 2012a), were used to compare temperature and precipitation patterns in Hausner's 1803-1830 period with a modern reference covering 1961-1990 (Fig. 10). The selection of the reference 1961-1990 period followed from WMO (2017) guidelines in which this period "has been retained as a standard reference period for long-term climate change assessments". Variability in monthly temperatures was characterized by standard deviation, while variation coefficient was applied to monthly precipitation. Series of seasonal temperature and precipitation indices for Buchlovice $\left(\varphi=49^{\circ} 05^{\prime} 06^{\prime \prime} \mathrm{N}\right.$, $\lambda=17^{\circ} 20^{\prime} 04^{\prime \prime} \mathrm{E}, H=264 \mathrm{~m}$ a.s.1.) interpreted from Hausner's records were compared with temperature and precipitation series for Brno using Pearson correlation coefficients (evaluated at the 0.05 significance level) and by graphical expression (Figs. 11-12). Finally, the numbers of days with selected climatological characteristics (precipitation days, cloudiness, strong wind, fog, thunderstorm) at Buchlovice in 1803-1830 were used to compare their annual variations with those corresponding to 1961-1990 at the Brno airport station, the Buchlovice rain-gauge station $\left(\varphi=49^{\circ} 05^{\prime} 15^{\prime \prime} \mathrm{N}, \lambda=17^{\circ} 20^{\prime} 44^{\prime \prime} \mathrm{E}, H=268 \mathrm{~m}\right.$ a.s.l.) and the Staré Město meteorological station $\left(\varphi=49^{\circ} 05^{\prime} 30^{\prime \prime} \mathrm{N}\right.$, $\lambda=17^{\circ} 25^{\prime} 54^{\prime \prime} \mathrm{E}, H=221 \mathrm{~m}$ a.s.1.) (Fig. 13).

\section{Results}

\subsection{Individual meteorological elements and phenomena}

\subsubsection{Air temperature}

Based on the criteria reported in Sect. 4.2, series of weighted temperature indices, $I_{\mathrm{T}}$, for Buchlovice in 1803-1830 were created (Table 1). As follows from fluctuations of annual temperature indices (Fig. 5a), the year 1822 was interpreted as the warmest $\left(I_{\mathrm{T}}=9\right)$ and 1805 as the coldest $\left(I_{\mathrm{T}}=-16\right)$. The year 1829 was also very cold $\left(I_{\mathrm{T}}=-13\right)$ and a remark- 

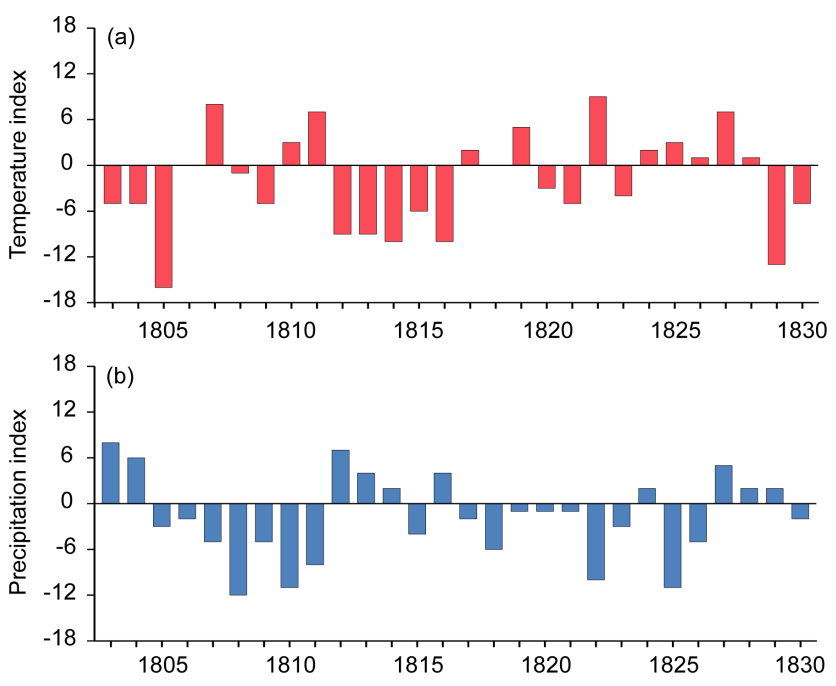

Figure 5. Fluctuations in annual temperature (a) and precipitation (b) indices at Buchlovice during 1803-1830 as derived from the weather diary kept by Šimon Hausner.

ably cold period occurred in 1812-1816. In terms of individual seasons (winter - DJF, spring - MAM, summer JJA, autumn $-\mathrm{SON}$ ), $I_{\mathrm{T}}$ values corresponding to the coldest seasons were higher than those of the warmest seasons $(-8$ for $1829 / 1830$ and 5 for $1821 / 1822$ for DJF, -5 for 1805 in MAM and SON and 3 for several years in MAM and SON) except JJA, for which the highest index (8) was achieved in 1811 and the lowest $(-6)$ in 1821.

Information concerning temperature indices may be supplemented by records of late frosts (April-June) causing damage to agricultural crops, depending on their stages of phenophase. Severe cold snaps in May, expressed by frost and damage, were not explicitly mentioned in 1803-1805 but there are reports of a need of "fur coats and a heated room" on 17 and 20 May 1803, 13-14 May 1804, and 24-25 May 1805. On 24 June 1806, frost damaged cucumbers. Grapevines, maize, and beans suffered severe frost on 6 June 1810. Despite severe frosts recorded during 2627 May 1812, Hausner reported no damage to crops. Severe frosts during 28-30 April 1814 ("ice an inch [ca. $2.6 \mathrm{~cm}$ ] deep on the water") damaged grapevines and fruit trees ("blossoms and the leaves on the trees as if scalded by hot water") (AS3, p. 301); frosts also returned on 11-13 May. After severe frosts on 16-20 April 1815, Hausner reported lesser frosts on 29-30 May that damaged beans again. After reporting how useful "a fur coat and a heated room" were in May 1818, Hausner recorded a severe frost on 1 June that froze cucumbers and beans planted in higher positions. Severe frosts on 21-22 June 1821 damaged cucumbers and beans in lower positions, as well as beans and potatoes in higher locations. A "strong" frost on 15 May 1825 damaged the greater part of the vineyards around Buchlovice, as well as maize and cucumbers. The summary evaluation of a very

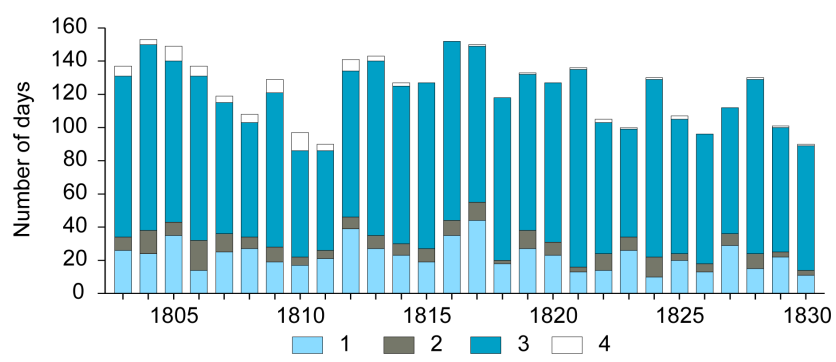

Figure 6. Fluctuations in the annual number of precipitation days (1 - solid, 2 - mixed, 3 - liquid) at Buchlovice during 1803-1830 derived from the weather diary kept by Šimon Hausner (4 - missing days).

cold January in 1820 is also interesting, when Hausner noted that "many people froze through their own fault because they drank a little more" (AS3, p. 529).

\subsubsection{Precipitation}

Based on the criteria reported in Sect. 4.2, series of weighted precipitation indices, $I_{\mathrm{P}}$, for Buchlovice in the 1803-1830 period were created (Table 2). As follows from fluctuations of annual precipitation indices (Fig. 5b), the year 1803 was interpreted as the wettest $\left(I_{\mathrm{P}}=8\right)$ and the year 1808 as the driest $\left(I_{\mathrm{P}}=-12\right)$, followed by 1810 and $1825\left(I_{\mathrm{P}}=-11\right)$. A markedly consistent drier period occurred in 1805-1811. Extreme values of $I_{\mathrm{P}}$ for individual seasons were the following. DJF: 4 for $1826 / 1827$ and -6 for $1812 / 1813$ and $1820 / 1821$, MAM: 4 for 1812 and -5 for 1808 and 1825; JJA: 5 for 1813 and -7 for 1808 , and SON: 3 for 1813 and -7 for 1815 .

The precipitation indices may be supplemented by annual numbers of precipitation days (Fig. 6). After a maximum in 1804 ( $150 \mathrm{~d}, 3 \mathrm{~d}$ of Hausner's observations missing), these numbers decreased to minima in 1810 and 1811 (86 d each, 11 and 4 missing days, respectively). Between 1812 and 1821 , the frequencies of precipitation days were higher than $120 \mathrm{~d}$ per year, with maxima in 1816 and 1817 (152 and $149 \mathrm{~d}$, respectively, $1 \mathrm{~d}$ missing in 1817). After 1821 , frequencies fluctuated around $100 \mathrm{~d}$ per year except for two local peaks in 1824 and 1828. Liquid (rain, drizzle) precipitation clearly prevailed in all years recorded. Solid precipitation (snow, ice pellets, hail) reached a maximum in 1817 , while mixed precipitation (previous types of precipitation with rain) prevailed in 1806 (6 d missing).

Torrential rain doing damage constitutes an important element of precipitation patterns. A downpour with thunderstorm on 22 May 1805 was the heaviest that Hausner had experienced in Buchlovice up to that time. He reported damaging torrential rain with a very violent thunderstorm on 26 April 1808 for Osvětimany, Stříbrnice, and Polešovice; the damage was particularly acute in Polešovice. At the same time, rain mixed with hail fell at Buchlovice. Rain accompanying a thunderstorm on 25 June 1808 was so heavy that it 
Table 1. Weighted 7-degree temperature indices reconstructed from the daily weather records kept by Šimon Hausner in Buchlovice, 18031830.

\begin{tabular}{|c|c|c|c|c|c|c|c|c|c|c|c|c|c|c|c|c|c|}
\hline Year & $\mathrm{J}$ & $\mathrm{F}$ & $\mathrm{M}$ & A & $\mathrm{M}$ & $\mathrm{J}$ & $\mathrm{J}$ & A & S & $\mathrm{O}$ & $\mathrm{N}$ & $\mathrm{D}$ & DJF & MAM & JJA & SON & Annual \\
\hline 1803 & -1 & -1 & 0 & 1 & 0 & 0 & 0 & 0 & -2 & -1 & 0 & -1 & - & 1 & 0 & -3 & -5 \\
\hline 1804 & 2 & 0 & -1 & 0 & 0 & 0 & 0 & -1 & 0 & 0 & -3 & -2 & 1 & -1 & -1 & -3 & -5 \\
\hline 1805 & -1 & -1 & -2 & -2 & -1 & -1 & -1 & -2 & 0 & -3 & -2 & 0 & -4 & -5 & -4 & -5 & -16 \\
\hline 1806 & 1 & 1 & 0 & -1 & -1 & -1 & -1 & 0 & 1 & -1 & 1 & 1 & 2 & -2 & -2 & 1 & 0 \\
\hline 1807 & 1 & 1 & -2 & -1 & 1 & 0 & 1 & 3 & 1 & 1 & 1 & 1 & 3 & -2 & 4 & 3 & 8 \\
\hline 1808 & 0 & -1 & -3 & -1 & 1 & 1 & 2 & 2 & 2 & 0 & -2 & -2 & 0 & -3 & 5 & 0 & -1 \\
\hline 1809 & -1 & -1 & -3 & -2 & 1 & 0 & 0 & 2 & 0 & -1 & -1 & 1 & -4 & -4 & 2 & -2 & -5 \\
\hline 1810 & -1 & 0 & 1 & 0 & 0 & -1 & 0 & 1 & 2 & 0 & 1 & 0 & 0 & 1 & 0 & 3 & 3 \\
\hline 1811 & -1 & -1 & 0 & 0 & 3 & 3 & 3 & 2 & 0 & 1 & -1 & -2 & -2 & 3 & 8 & 0 & 7 \\
\hline 1812 & -1 & 0 & 1 & -3 & 0 & 0 & -1 & -1 & -2 & 2 & -2 & -2 & -3 & -2 & -2 & -2 & -9 \\
\hline 1813 & -2 & 0 & -2 & 0 & 0 & -2 & -1 & 0 & -1 & -1 & -1 & 1 & -4 & -2 & -3 & -3 & -9 \\
\hline 1814 & 0 & -3 & 0 & 0 & -3 & -2 & 0 & 0 & -2 & 0 & 0 & 0 & -2 & -3 & -2 & -2 & -10 \\
\hline 1815 & 0 & 0 & 1 & 0 & 0 & 0 & -2 & -1 & -1 & 0 & -1 & -2 & 0 & 1 & -3 & -2 & -6 \\
\hline 1816 & 1 & 0 & -1 & 0 & 0 & -1 & -2 & -2 & -2 & -1 & -1 & -1 & -1 & -1 & -5 & -4 & -10 \\
\hline 1817 & 1 & 1 & 0 & -3 & 0 & 2 & 0 & 0 & 1 & 0 & 0 & 0 & 1 & -3 & 2 & 1 & 2 \\
\hline 1818 & 0 & 0 & 0 & 1 & 0 & 0 & 1 & 1 & 0 & 0 & -1 & -2 & 0 & 1 & 2 & -1 & 0 \\
\hline 1819 & -1 & 1 & 1 & 2 & 0 & 1 & 1 & 0 & 1 & 0 & 0 & -1 & -2 & 3 & 2 & 1 & 5 \\
\hline 1820 & -2 & 0 & -1 & 1 & 0 & -2 & -1 & 2 & 0 & 1 & 0 & -1 & -3 & 0 & -1 & 1 & -3 \\
\hline 1821 & 1 & -2 & -1 & 2 & -1 & -3 & -2 & -1 & -1 & 0 & 1 & 2 & -2 & 0 & -6 & 0 & -5 \\
\hline 1822 & 2 & 1 & 1 & 1 & 1 & 1 & 1 & 0 & 0 & 2 & 0 & -1 & 5 & 3 & 2 & 2 & 9 \\
\hline 1823 & -3 & 0 & 0 & -1 & 0 & -1 & -1 & 1 & 1 & 0 & 0 & 0 & -4 & -1 & -1 & 1 & -4 \\
\hline 1824 & 0 & 1 & 0 & 0 & -2 & -1 & -1 & 0 & 1 & 1 & 1 & 2 & 1 & -2 & -2 & 3 & 2 \\
\hline 1825 & 2 & -1 & -1 & 0 & 0 & 0 & 0 & 0 & 0 & 0 & 1 & 2 & 3 & -1 & 0 & 1 & 3 \\
\hline 1826 & -2 & -1 & 0 & -1 & -2 & 0 & 2 & 2 & 1 & 1 & 0 & 1 & -1 & -3 & 4 & 2 & 1 \\
\hline 1827 & 0 & -2 & 0 & 1 & 2 & 2 & 2 & 1 & 1 & 1 & -1 & 0 & -1 & 3 & 5 & 1 & 7 \\
\hline 1828 & 1 & -1 & 1 & 1 & 0 & 0 & 2 & -2 & 0 & -1 & 0 & 0 & 0 & 2 & 0 & -1 & 1 \\
\hline 1829 & -1 & -2 & -2 & 0 & -1 & -1 & 1 & -1 & 1 & -1 & -3 & -3 & -3 & -3 & -1 & -3 & -13 \\
\hline 1830 & -3 & -2 & 0 & 0 & 0 & 1 & 1 & 1 & -2 & -1 & 0 & 0 & -8 & 0 & 3 & -3 & -5 \\
\hline
\end{tabular}

"did great damage in some places" (AS3, p. 116). Heavy, torrential rain on 28 May 1810 flooded all the meadows and gave rise to a flash flood that swept away animals as well as wooden laths, and beams and other items; even the oldest people in Buchlovice could not recall a comparable event. Torrential rain on 2 June 1814 flooded meadows and spoiled the hay. Only general "damage" was reported after a heavy downpour accompanied by small hailstones associated with a thunderstorm on 27 May 1819. A heavy downpour on 19 August 1821 flooded meadows, as did otherwise unspecified heavy rain in June 1827. Extraordinarily torrential rain on 12 June 1825, accompanied by an "awful" thunderstorm, flooded meadows, did heavy damage to field crops (hail), swept away houses (flash flood), and cost three people their lives.

\subsubsection{Cloudiness}

Cloudiness was derived from Hausner's records of sunshine and clouds. Because of interpretation in terms of clear sky, half-covered sky, and overcast sky - divided into the whole day, night, and morning hours, and afternoon and evening hours, five intervals were defined for cloudiness: (1) clear sky, (2) clear sky in one part of the day and half-covered sky in the other part, (3) half-covered sky, (4) half-covered sky in one part of the day and overcast in the other part, and finally (5) overcast. As is evident from Fig. 7, Hausner's records did not permit interpretation of cloudiness patterns in the greater parts of the days in 1803-1812 (maximum $90 \mathrm{~d}$ in 1806). This was also reflected in smaller proportions of cloudy days (i.e. with cloudiness in categories 2, 3, and 4). Despite $69 \mathrm{~d}$ with non-interpreted cloudiness and some missing reports in 1811, the highest number of clear days (103) and a lowest number of overcast days (104) were derived. This correlates well with warmer patterns in MAM-JJA and drier patterns in JJA-SON of this year (Tables 1 and 2). The warmest, also somewhat drier, year of 1822 had the highest number of cloudy days (172) and also an above-mean number of clear days (82) and a below-mean number of overcast days (105); $6 \mathrm{~d}$ were without cloudiness interpretation. The lowest number of 59 clear days was derived for 1828 and the highest number of 175 overcast days for 1820 . 
Table 2. Weighted 7-degree precipitation indices reconstructed from daily weather records kept by Šimon Hausner in Buchlovice, 18031830 .

\begin{tabular}{|c|c|c|c|c|c|c|c|c|c|c|c|c|c|c|c|c|c|}
\hline Year & $\mathrm{J}$ & $\mathrm{F}$ & $\mathrm{M}$ & A & $\mathrm{M}$ & $\mathrm{J}$ & $\mathrm{J}$ & A & $S$ & $\mathrm{O}$ & $\mathrm{N}$ & $\mathrm{D}$ & DJF & MAM & JJA & SON & Annual \\
\hline 1803 & 2 & 0 & 0 & 0 & 2 & 1 & 0 & 0 & 0 & 1 & 0 & 2 & - & 2 & 1 & 1 & 8 \\
\hline 1804 & 1 & 0 & 0 & 3 & -1 & 1 & 1 & 0 & 0 & 0 & 1 & 0 & 3 & 2 & 2 & 1 & 6 \\
\hline 1805 & -2 & 1 & 0 & 0 & 2 & 0 & -2 & 0 & 0 & 0 & -2 & 0 & -1 & 2 & -2 & -2 & -3 \\
\hline 1806 & 1 & 1 & 1 & -1 & -2 & -3 & 0 & 2 & 2 & -2 & 0 & -1 & 2 & -2 & -1 & 0 & -2 \\
\hline 1807 & 0 & 1 & -1 & -1 & -1 & -1 & 0 & -2 & -2 & -1 & 2 & 1 & 0 & -3 & -3 & -1 & -5 \\
\hline 1808 & -1 & -1 & -3 & 0 & -2 & -2 & -3 & -2 & 2 & -1 & 0 & 1 & -1 & -5 & -7 & 1 & -12 \\
\hline 1809 & 0 & 0 & -2 & 0 & -2 & -2 & -2 & 0 & 1 & 0 & 0 & 2 & 1 & -4 & -4 & 1 & -5 \\
\hline 1810 & -3 & 0 & 0 & 0 & 0 & -3 & -1 & -1 & -1 & -2 & -1 & 1 & -1 & 0 & -5 & -4 & -11 \\
\hline 1811 & 0 & -1 & 0 & 1 & 0 & -1 & -1 & -2 & -1 & -2 & -2 & 1 & 0 & 1 & -4 & -5 & -8 \\
\hline 1812 & 0 & 0 & 3 & 0 & 1 & 0 & 1 & 0 & -1 & 1 & 2 & 0 & 1 & 4 & 1 & 2 & 7 \\
\hline 1813 & -3 & -3 & 0 & 0 & 1 & 2 & 2 & 1 & 1 & 2 & 0 & 1 & -6 & 1 & 5 & 3 & 4 \\
\hline 1814 & 1 & -1 & -1 & -1 & -1 & 3 & -1 & 1 & 1 & 0 & -1 & 2 & 1 & -3 & 3 & 0 & 2 \\
\hline 1815 & 1 & -1 & 1 & 0 & -1 & 2 & 1 & 1 & -3 & -2 & -2 & -1 & 2 & 0 & 4 & -7 & -4 \\
\hline 1816 & 0 & 0 & 0 & 0 & 2 & 1 & 2 & 0 & 0 & 0 & 0 & -1 & -1 & 2 & 3 & 0 & 4 \\
\hline 1817 & -1 & 1 & 1 & 1 & 0 & 0 & 0 & 0 & -2 & 1 & -3 & 0 & -1 & 2 & 0 & -4 & -2 \\
\hline 1818 & -2 & -1 & 0 & -1 & 1 & -1 & 1 & 0 & 0 & 0 & -1 & -2 & -3 & 0 & 0 & -1 & -6 \\
\hline 1819 & -1 & 1 & 0 & 0 & 0 & 0 & 0 & 1 & -2 & 0 & 0 & 0 & -2 & 0 & 1 & -2 & -1 \\
\hline 1820 & 1 & 0 & 0 & -1 & 2 & 1 & -1 & -1 & 0 & 0 & 0 & -2 & 1 & 1 & -1 & 0 & -1 \\
\hline 1821 & -2 & -2 & 0 & 0 & 0 & 1 & 2 & 1 & 1 & -1 & 0 & -1 & -6 & 0 & 4 & 0 & -1 \\
\hline 1822 & 1 & -3 & 1 & -1 & -1 & -1 & 0 & 0 & 0 & -3 & -1 & -2 & -3 & -1 & -1 & -4 & -10 \\
\hline 1823 & -1 & 2 & -2 & -2 & 0 & 0 & 1 & 1 & -1 & 0 & -1 & 0 & -1 & -4 & 2 & -2 & -3 \\
\hline 1824 & -1 & -1 & -1 & 1 & 1 & 1 & 1 & 0 & -1 & 1 & 1 & 0 & -2 & 1 & 2 & 1 & 2 \\
\hline 1825 & 0 & -2 & -1 & -2 & -2 & 0 & -1 & -1 & -1 & 0 & 0 & -1 & -2 & -5 & -2 & -1 & -11 \\
\hline 1826 & -1 & 0 & 0 & -1 & 0 & 0 & -1 & -2 & -2 & 1 & 1 & 0 & -2 & -1 & -3 & 0 & -5 \\
\hline 1827 & 2 & 2 & 2 & 0 & 0 & 1 & -3 & 0 & -1 & 0 & 2 & 0 & 4 & 2 & -2 & 1 & 5 \\
\hline 1828 & 1 & 1 & 0 & 0 & 1 & 1 & 0 & 0 & -1 & 0 & -1 & 0 & 2 & 1 & 1 & -2 & 2 \\
\hline 1829 & 1 & -1 & 0 & 2 & 0 & 0 & 0 & 0 & 0 & 0 & -1 & 1 & 0 & 2 & 0 & -1 & 2 \\
\hline 1830 & -1 & 1 & -1 & 2 & 0 & -1 & -1 & -1 & 2 & 0 & -2 & 0 & 1 & 1 & -3 & 0 & -2 \\
\hline
\end{tabular}

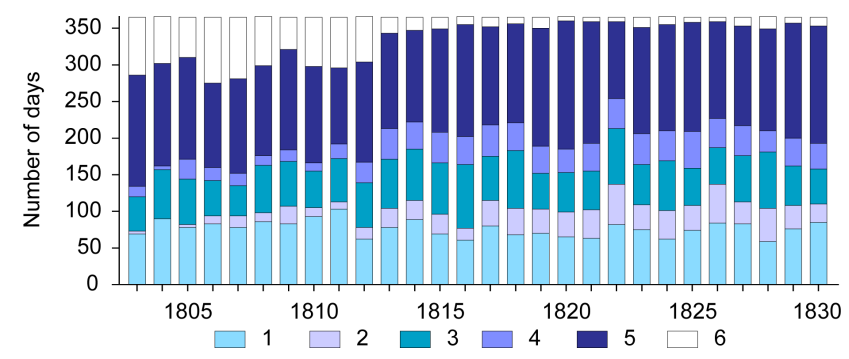

Figure 7. Fluctuations in annual cloudiness at Buchlovice during 1803-1830 derived from the weather diary kept by Šimon Hausner: (1) clear sky, (2) clear sky in one part of the day and half-covered sky in the other part, (3) half-covered sky, (4) half-covered sky in one part of the day and overcast in the other part, (5) overcast, and (6) missing days or no information related to cloudiness.

\subsubsection{Wind}

Figure 8a shows fluctuations in the annual frequency of days with strong winds at Buchlovice during 1803-1830. Days upon which Hausner mentioned strong or very strong winds (very windy weather, "awful" wind, extraordinary wind, windstorm, or blizzard) were interpreted as having strong winds (see Sect. 4.1, point iv). Their frequency generally increased from the beginning of observations until 1808, when the highest frequency of $89 \mathrm{~d}$ was achieved ( $4 \mathrm{~d}$ missing from Hausner's observations). After that, a general decreasing tendency in the number of days with strong winds is noticeable. The lowest frequency was recorded only 2 years after the absolute maximum in 1808: $49 \mathrm{~d}$ with strong winds in 1810; however, a total of $11 \mathrm{~d}$ are missing from Hausner's observations.

Information concerning strong winds may be supplemented by the quite natural attention drawn to severe events. Hausner made several records of "awful" or very strong whirlwinds of short duration: on 14 November 1806 people were knocked to the ground, and 14 March 1817, 7 June 1819, 15 and 20 June 1822, and 29 June 1825 were also notable. However, the only "whirlwind", on 14 May 1823, could be considered a probable tornado, accompanied by thunderstorm and downpour, because of the extensive damage recorded, particularly to roofs, barns, and houses. But damage done by strong winds is described only very briefly in Hausner's records. Damaging wind- 

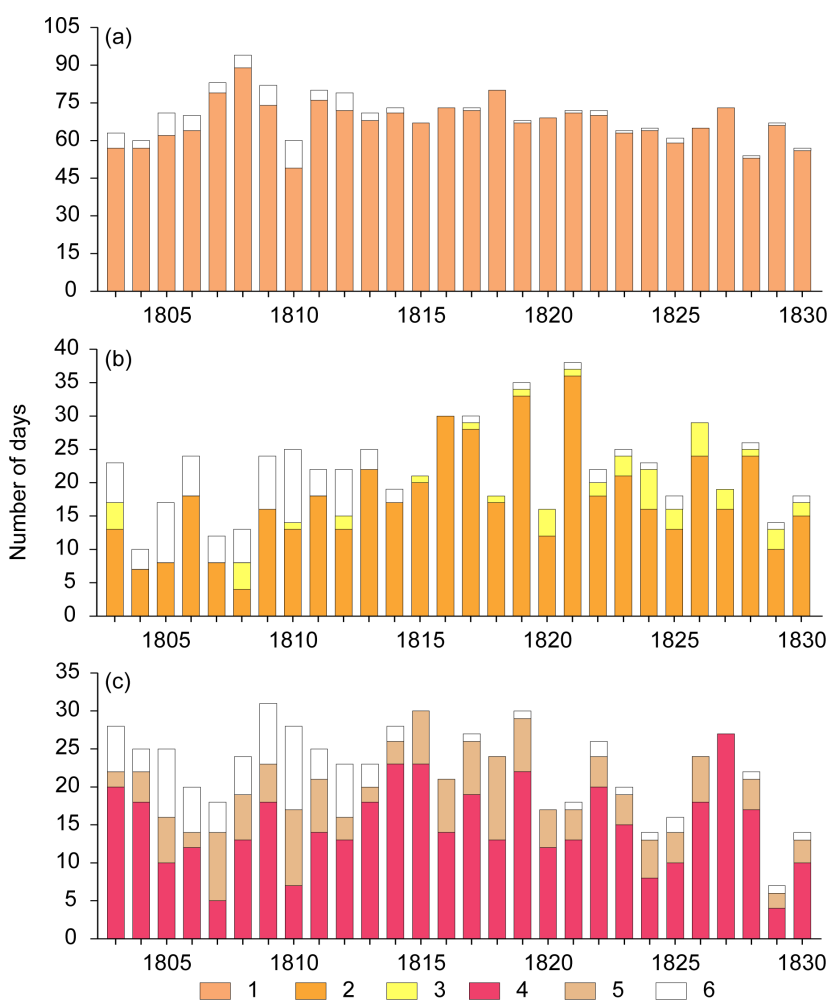

Figure 8. Fluctuations in the annual number of days with selected phenomena at Buchlovice during 1803-1830 derived from the weather diary kept by Šimon Hausner: (a) strong wind (1); (b) fog (2 - fog, 3 - foggy); (c) thunderstorm (4 - at Buchlovice, 5 - distant thunderstorm) (6- missing days).

storms may be attributed with a high degree of possibility to events on 30 April 1814 (many branches of trees broken), 26 July 1822 (much damage), and 26 May 1830 (broken trees, together with thunderstorm and downpour). During a heavy blizzard on 24 November 1815 it was not possible to walk or even to ride with wagons (similarly harrowing winds also occurred on 7-9 December). Records of people knocked to the ground (albeit the frailer people) by wind were reported for 12 May 1810, 11 February 1821, and 24 August 1828 . It was barely possible to walk during very strong winds on 29 March 1811 and 7 December 1812. On $29 \mathrm{Au}-$ gust 1818 and 2 September 1826, Hausner reported winds strong enough to knock fruit from the trees. A violent wind on 4 March 1808 "made the windows noisy" (AS3, p. 107) and a windstorm on 5 July 1817 was described as "wanting to tear everything [down]" (AS3, p. 423).

\subsubsection{Fog and thunderstorm}

Fluctuations in the annual numbers of days with fog (or foggy weather) appear in Fig. 8b and show quite inconsistent patterns during the $1803-1830$ period. Some years, especially around the beginning of the observation period, appear to be underestimated (e.g. 1804, 1805, 1807, and 1808;
Hausner's observations lack 3, 9, 4, and 5 d, respectively). On the other hand, certain annual numbers of days with fog appear very high (e.g. $36 \mathrm{~d}$ in 1821 and 33 in $1819-1 \mathrm{~d}$ missing from both; partly so in 1816 with 30, and 1817 with 28 such days, $1 \mathrm{~d}$ missing).

Annual frequencies of days with thunderstorm, divided into those occurring directly over Buchlovice and those further off (distant thunderstorms), fluctuate over a broad range (Fig. 8c): 30 such days were recorded in 1815 ( $29 \mathrm{~d}$ in 1819 , $1 \mathrm{~d}$ missing) against only $6 \mathrm{~d}$ in 1829 . Even though the lastmentioned is significantly below the other lowest frequencies (13 $\mathrm{d}$ in 1824 and 1830), the style and density of daily records for 1829 do not give rise to grounds for uncertainty ( $1 \mathrm{~d}$ missing in all 3 years).

Heavy thunderstorms accompanied by damaging torrential rain, strong winds, and/or hail, have already been reported. Lightning strikes are another peril of such events. Three consecutive strikes at Buchlovice on 4 August 1806 damaged a house, set the roof of a cellar on fire, and damaged the tower and roof of the church. Hausner reported that Mařatice suffered a lightning strike and resultant fire on 2 August 1809. On 21 September 1813, during an intense thunderstorm with heavy downpour, lightning strikes hit Polešovice, Napajedla, and Střílky, and started fires everywhere. He further mentions a terrible thunderstorm on 29 May 1826 in Koryčany but supplies no further details. Yet another awful thunderstorm on 10 July 1828 led to flooded meadows and the hail that accompanied it bruised grain, maize, vegetables, and fruit trees along a broad belt.

\subsection{Phenological data and agricultural work}

Hausner's diaries also recorded certain phenophases and aspects of agricultural work directly attributable to the weather. In the course of the year, these entries could include the time at which spring sowing of cereals took place, the first tasks in vineyards, the blossoming of fruit trees and grapevines, the grain harvest, autumn sowing, and wine vintage. Fluctuations in the longest available series of such matters appear in Fig. 9. The start of spring sowing (particularly barley; 4 years missing in the series) fluctuated between 2 March (1822) and 14 April (1812) (Fig. 9a). The appearance of blossom on fruit trees was noted for several species. The most complete series were those for apricots, cherries, and pears. Since series bias could arise out of the mixture of blossoming for early and late species, only the dates for cherries were employed (5 years missing): their earliest blossoming was recorded for 15 April 1806, the latest for 10 May 1817 (Fig. 9b). The grapevines (Fig. 9c) blossomed earliest on 29 May 1822 and latest on 3 July 1814 (4 years missing). Although Hausner often specified individual species for grain harvests, only series of general grain harvest beginnings (Fig. 9d) were long enough for validity ( 3 years missing), fluctuating between 26 June (1811) and 5 August (1816). 


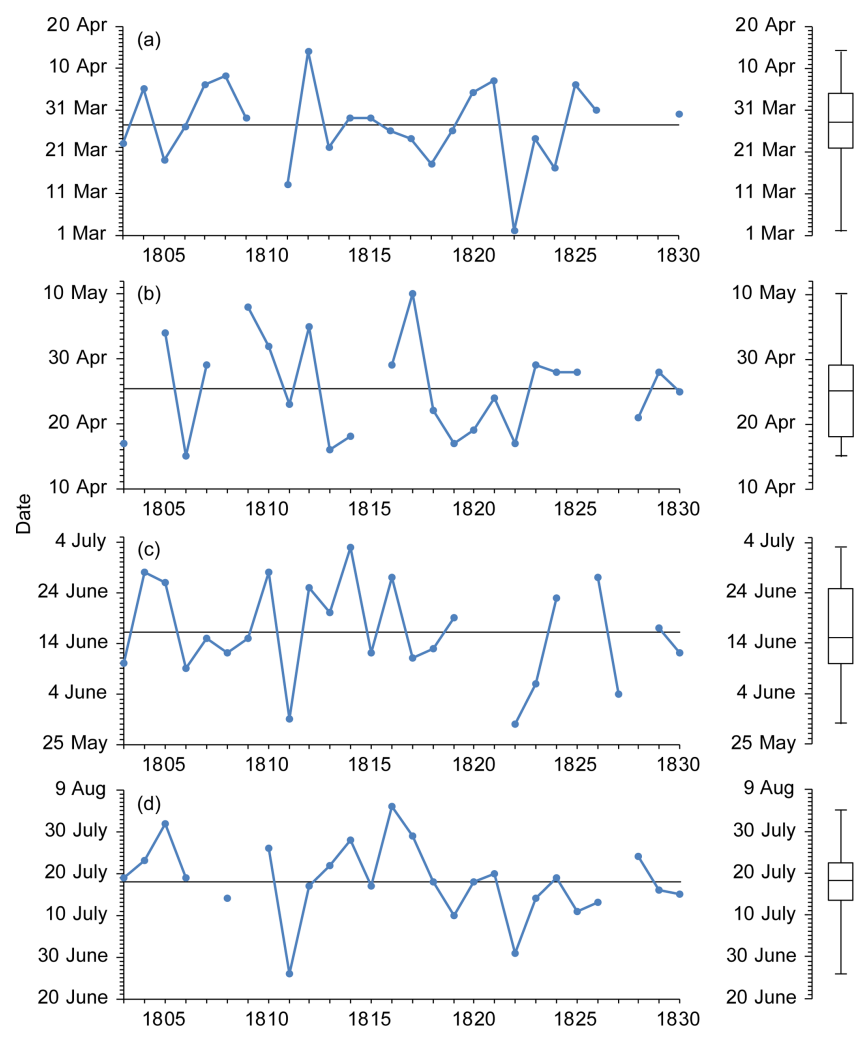

Figure 9. Fluctuations (left) and box plots (right) of the beginnings of selected phenophases and agricultural work at Buchlovice during 1803-1830 derived from the weather diary kept by Šimon Hausner: (a) spring sowing of cereals; (b) blossoming of cherry trees; (c) blossoming of grapevine; (d) grain harvest.

Some remarkably early - or late - beginnings correlated well with extreme temperature patterns (compare Fig. 9 with Table 1). Extremely early sowing in 1822 followed a very warm DJF in $1821 / 1822$ and a considerably late sowing in 1812 followed a remarkably cold April. The latest blossoming of cherry trees, in 1817 , can also be attributed to an exceedingly cold April. A very early blossoming of grapevine and gathering of the grain harvest in 1811 reflected intensely warm patterns in May and June; blossoming of grapevine only a day earlier in 1822 followed a long warm period that had started as early as in November 1821 . On the other hand, the latest blossoming, recorded in 1814, was related to an exceedingly cold May and very cold June. The latest grain harvest in 1816 (known as "the year without a summer" after the catastrophic Tambora volcanic eruption; Luterbacher and Pfister, 2015) was related to cold June-July patterns.

\section{Discussion}

\subsection{Uncertainties in Hausner's observations}

Hausner's style of keeping daily weather records and its systematic character, featuring a very low number of missing daily observations, leads to the assumption that he was a meticulous observer, and his observations gain a great deal of credibility thereby. Of course, as with other personal daily weather observations, a degree of subjectivity is inherent in his records, but it appears to have been kept to a minimum. But it is difficult to estimate how much was Hausner influenced in his weather observation by experience before their beginning in 1803 and how changed his weather perception during the following 28 years of his records. He could not observe the full $24 \mathrm{~h}$ of a day, i.e. he might miss some phenomena; for example, those that took place at night if they left no imprint in the morning (perhaps the occurrence of light rain, short-term fog, etc.). These facts may find slight reflections in the frequencies of a few meteorological characteristics presented in Sect. 5. We therefore present some comparisons of Hausner's records with events documented by other sources.

The taxation records kept for the Buchlov domain mention a number of severe events that provided sufficient grounds for tax alleviation for the farmers affected, a bureaucratic process that left a distinct paper trail (see Brázdil et al., 2012b). For example, on 4 June 1820 local torrential rain with hail did damage to agricultural crops in Žeravice (AS4, fol. 5rv, 7rv). Although no such event appears in records for Buchlovice, Hausner wrote in his monthly summary for June of "heavy downpours during which great [quantities of] mud buried meadows" (AS3, p. 546). On 4 August 1823 hail led to damage in Stř́ibrnice, Osvětimany, and Žeravice (AS4, fol. 18rv); no indication of such an event appears in Hausner's records. An awful thunderstorm, torrential rain, hailstorm, and flash flood, with extensive damage, were reported in the broader area of south-eastern Moravia on 12 June 1825 (Brázdil et al., 2012b). Hausner described this outstanding event in great detail (AS3, p. 737): “[... faint sunrise, gloomy until 4 p.m., then awful thunderstorm together with [such an] exceptional cloudburst that all the meadows flooded, and houses were destroyed, [while] at Buchlovice two women and a child died; continuous north wind." Details of damage at seven villages appear in the taxation records of the Buchlov domain: five people died and 103 cattle perished, while 52 houses, 18 barns, and 63 cow sheds and stables were washed away (AS4, fol. 27rv). Hausner also included this in a monthly summary as a "terrible, dreadful downpour" (AS3, p. 739) with a detailed list of corresponding damage in his annual summary (ibid., p. 757): "[...] on 12 June, between 4 and 5 p.m., an awful thunderstorm occurred, cloudburst with hailstorm: young grapevines and grapes were knocked down, leaves and fruits torn from trees, beans, maize, cucumber, lettuce, cabbage, and kale fatally battered by hail. In many places grain totally battered down and tangled; in some places [only] less so, rye generally, wheat less, barley, oats [...] Due to a cloudburst, all meadows [so] clogged by stones and lumber that nobody will have any hay $[\ldots]$. ." 

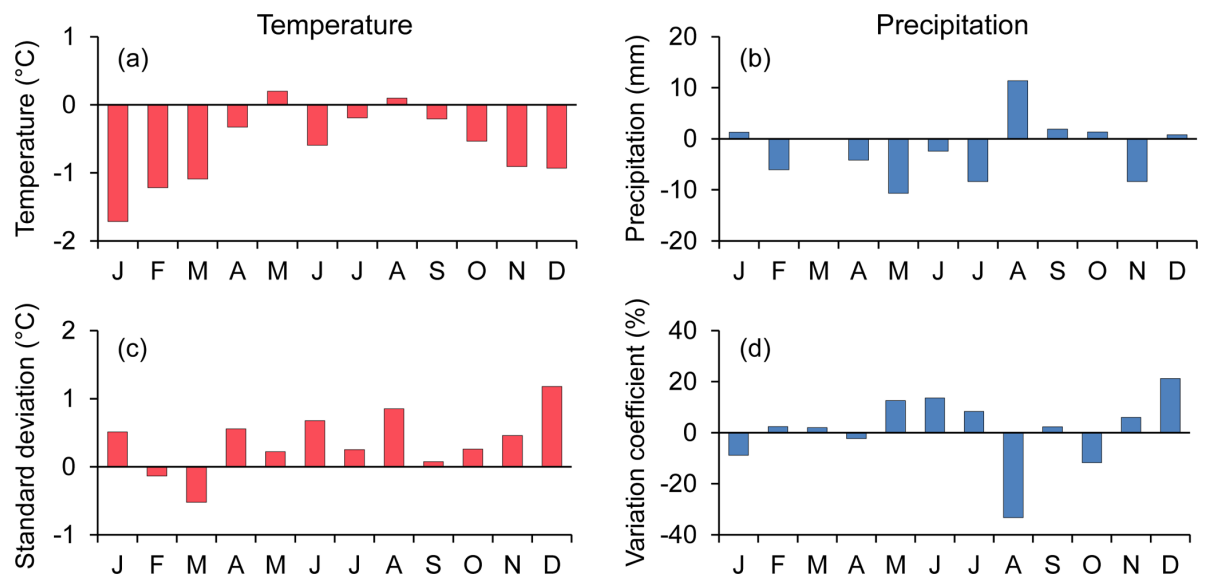

Figure 10. Comparison of monthly mean temperatures, precipitation totals, and their variability between the periods 1803 and 1830 and between 1961 and 1990 in Brno: differences in temperatures (a) and standard deviations (c), precipitation (b), and variation coefficients (d). Positive differences express higher values in 1803-1830 and negative differences in 1961-1990.

Hausner also mentioned an infamous flood that occurred in March 1830, following the extremely severe winter of 1829/1830 (Munzar, 2000; Munzar and Kakos, 2000). He reported it in a monthly summary (AS3, p. 906): "March very cold month, snow, plenty of ice, it froze heavily [...] melting started on 18th [March] and such a large amount of water [rose] that many bridges over the River Morava were damaged totally or partially." Hausner's note for 7 January 1831 is also interesting (AS3, p. 931): "In the evening, at 09:00 and 10:00 p.m., [the sky] was very red." This was caused by the aurora borealis, observed in Brno from 18:30 LT (local time, 06:30 p.m.) of this day to 02:00 LT (02:00 a.m.) of 8 January (Brázdil et al., 2005b).

\subsection{Hausner's observations and climate fluctuations}

Based on comparison of 1803-1830 with the reference period of 1961-1990 from the long temperature and precipitation series for Brno, the period of Hausner's observations was notably cooler in the winter half year (October-March) and in June compared to the reference; of the remaining months, only May and August were slightly warmer (Fig. 10a). With the exception of February and March, all months were also more variable according to the standard deviation than in the reference period (Fig. 10c). Wetter patterns in the Hausner period prevailed in August, when precipitation totals characterized by variation coefficient were significantly less variable (Fig. 10b, d). In contrast, drier patterns prevailed mainly in February, from April to July and in November (Fig. 10b); precipitation totals from May to July and in December were also more variable (Fig. 10d).

Fluctuations in seasonal temperature and precipitation indices, appearing in Tables 1 and 2, may be compared with seasonal temperature means and precipitation totals from observations at the Brno station in the 1803-1830 period (data for Brno are taken from Brázdil et al., 2012a). Seasonal temperatures (Fig. 11) offer the closest accordance between Hausner's Buchlovice series and the Brno series (expressed by Pearson correlation coefficient $r$ ) for DJF $(r=0.924)$, followed by MAM $(r=0.904)$ and JJA $(r=0.891)$. Consistency becomes lower in SON $(r=0.829)$. However, all correlation coefficients are statistically significant at the 0.05 significance level. The correlation coefficient for annual series $(r=0.912)$ is also statistically significant and very high.

Seasonal precipitation (Fig. 12), exhibits generally lower consistency between precipitation indices interpreted from Hausner's records for Buchlovice and measured totals in Brno. The JJA patterns show the highest similarity $(r=$ $0.920)$; lower correlations pertain to SON $(r=0.806)$, DJF $(r=0.779)$, and MAM $(r=0.757)$ patterns; however, all Pearson correlation coefficients are statistically significant at the 0.05 significance level. The correlation coefficient for annual precipitation series achieves the same value as that for SON.

Despite generally close agreement between the Hausner temperature and precipitation series and those for Brno, some instances of greater or smaller disagreement appear. This is particularly evident in interpretation of temperature/precipitation indices on a 7-degree ordinal scale (Pfister, 1992), an approach that cannot cover both positive and negative extremes well. Moreover, the interpretation of indices depends heavily on the comprehensiveness and degree of representation in Hausner's weather descriptions. These also depend on the intensity of weather manifestations, which is best expressed by DJF, MAM, and JJA temperatures and JJA precipitation (these are also expressed in the highest correlation coefficients appearing for these seasons and, with the exception of JJA, in higher values for temperatures compared with precipitation). While the distance between Brno and Buchlovice plays a generally negligible role in temperature patterns, the high spatial variability often associated with 

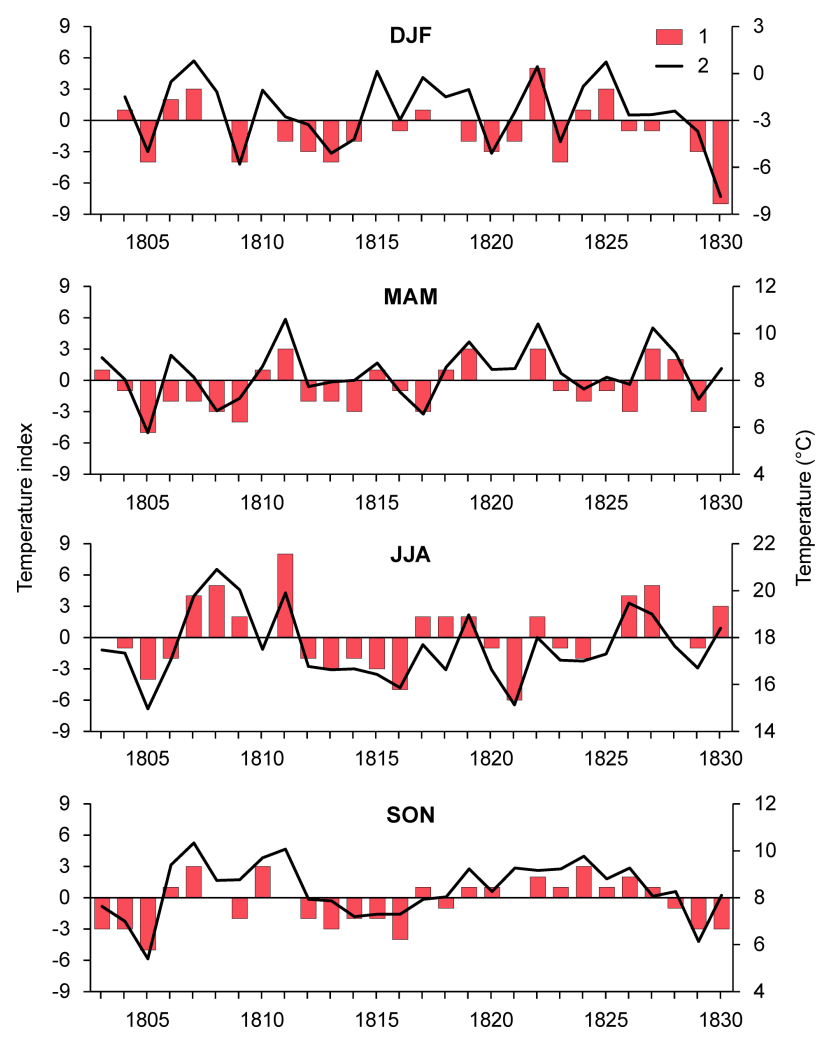

Figure 11. Fluctuations in weighted seasonal temperature indices in Buchlovice (1) and in mean seasonal temperatures in Brno (2) during the 1803-1830 period.

precipitation totals contributes to higher differences between the two places (Brázdil et al., 2012a).

Figure 13 compares annual variations in selected climatological characteristics at Buchlovice, as interpreted from Hausner's records for 1803-1830, with those from meteorological observations at the Brno, Buchlovice, and Staré Město stations in 1961-1990. Missing Hausner observations (see Fig. 4) lead to mean monthly values in Fig. 13a-d being maximally underestimated by between $0.36 \mathrm{~d}$ (February) and $0.11 \mathrm{~d}$ (September), assuming that the studied variables appeared in all the missing days. For annual values, the possible maximum underestimation might achieve $3.36 \mathrm{~d}$. The annual number of precipitation days according to Hausner's observations and to measurements at the Buchlovice rain-gauge station (Fig. 13a) is nearly the same (120.1 and $117.9 \mathrm{~d}$, respectively). Hausner recorded a higher frequency of such days especially in March, the summer months, and October, while from November to February their frequencies were lower. The annual number of days with strong winds in Buchlovice (Fig. 13b) is higher than at the Brno airport station (67.4 and $48.1 \mathrm{~d}$, respectively); the same holds for the monthly figures (except February) with a maximum in April in both series. The higher numbers of such days at Buchlovice may clearly be attributed to the qualitative evaluation of wind force by Hausner contrasting with the strictly

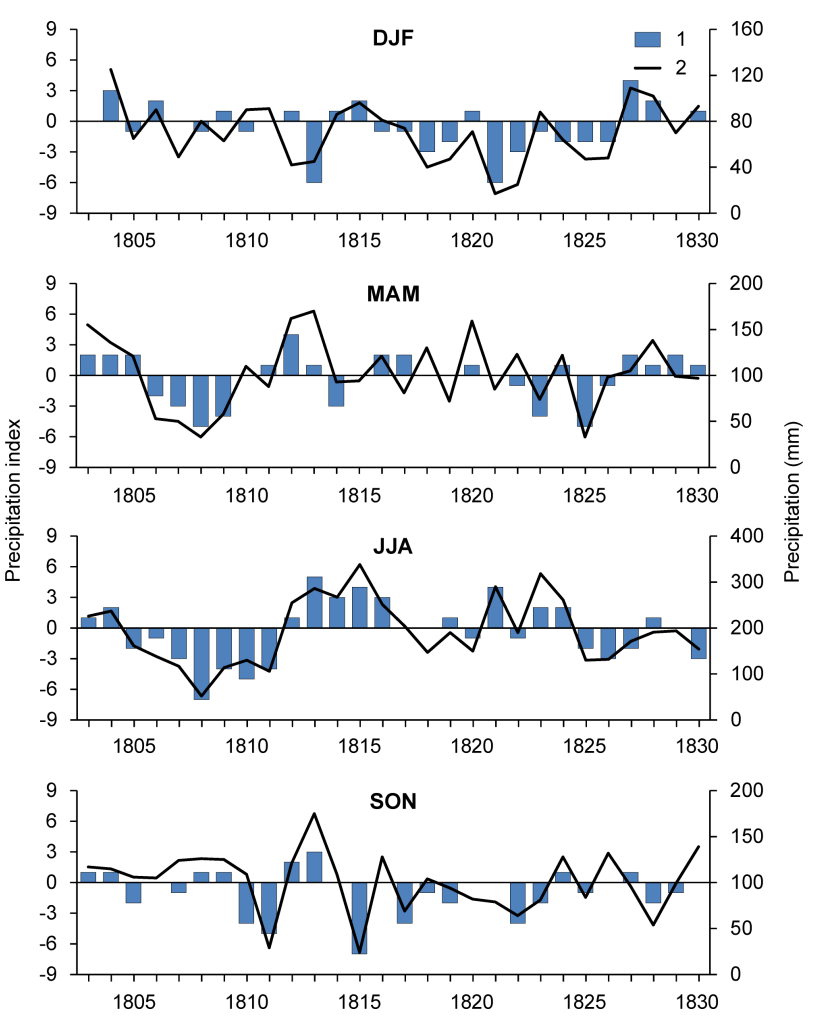

Figure 12. Fluctuations in weighted seasonal precipitation indices in Buchlovice (1) and in seasonal precipitation totals in Brno (2) during the 1803-1830 period.

selected wind-speed thresholds for Brno. The slightly higher annual numbers of days with thunderstorms (Fig. 13c) follow from Hausner's data compared with the Staré Město station (14.9 and $12.2 \mathrm{~d}$, respectively). Annual variations are nearly identical in general features for both Buchlovice and Staré Město, with a maximum in June. The number of days with fog (Fig. 13d) consists of a smoothed annual distribution with decreasing monthly frequencies from January to May-June followed by an increase towards December for Buchlovice. The Staré Město station shows a consistently higher number of such days, particularly from September to November (42 d with fog annually compared to 19.2 such days at Buchlovice). This may be attributed to the position of the Staré Město station in the valley of the River Morava, a location favouring the frequent occurrence of fog, as well as the use of a strict fog definition related to guidelines for meteorological observations. The horizon was also more-or-less limited in the vicinity of Hausner's dwelling in Buchlovice. A relatively simplified mode of expression was selected for comparison of cloudiness (Fig. 13e), dividing such days into those with clear sky, overcast sky, and the remainder (cloudy sky). The comparison of Hausner's records at Buchlovice with the Stare Město station is complicated by the annual absence of $31.8 \mathrm{~d}$ or any interpretable records of them. However, it appears that interpretation of Hausner's entries com- 

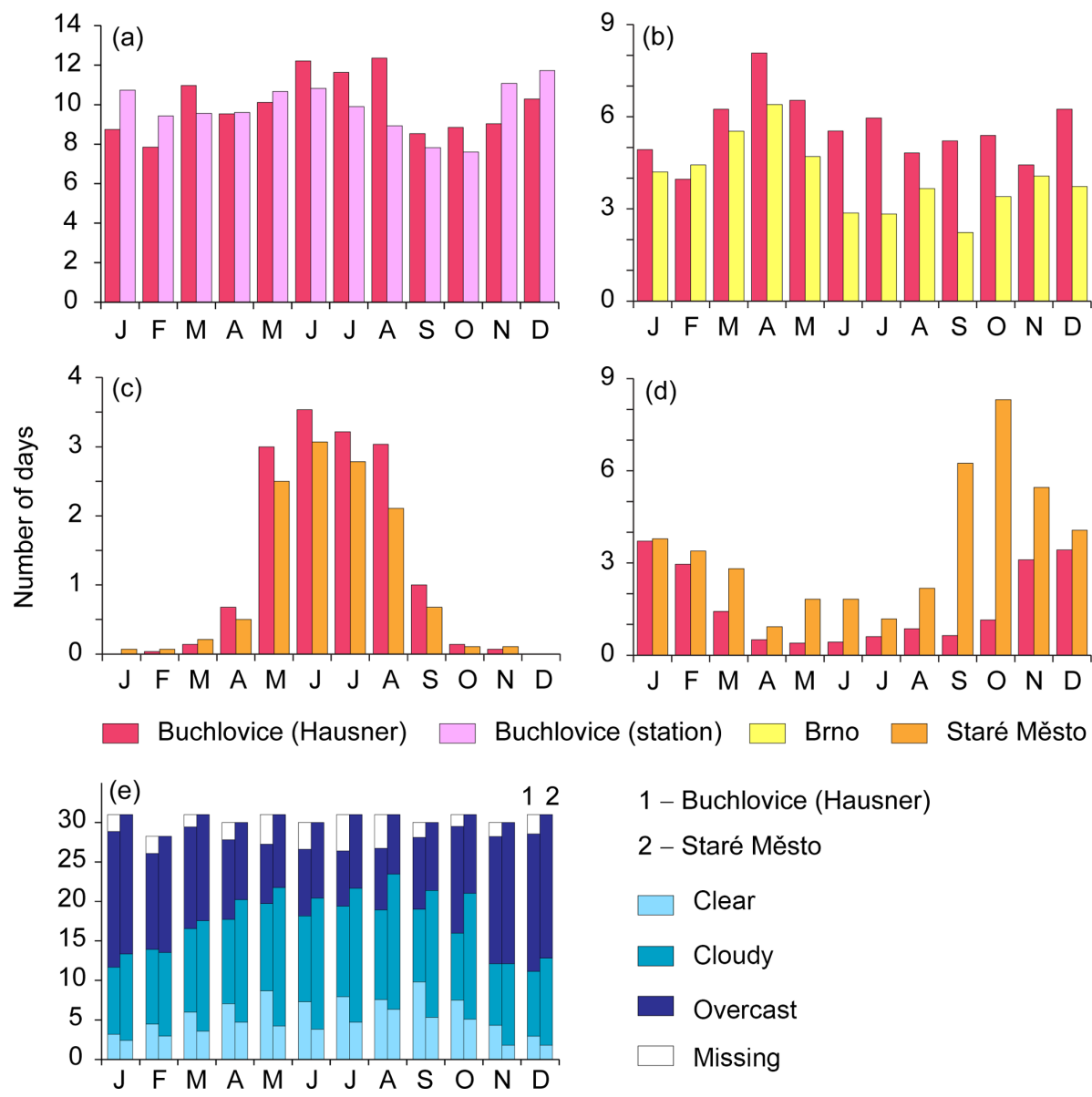

Figure 13. Comparison of annual variation in selected climatological characteristics at Buchlovice interpreted from Hausner's records for 1803-1830 and at three selected meteorological stations in 1961-1990: (a) number of precipitation days (with totals $\geq 0.1 \mathrm{~mm}$ for the Buchlovice rain-gauge station); (b) number of days with strong winds (with wind force $\geq 7^{\circ} \mathrm{B}$, i.e. wind speed $\geq 10.8 \mathrm{~m} \mathrm{~s}{ }^{-1}$ for Brno); (c) number of days with thunderstorm; (d) number of days with fog; (e) number of days with various degrees of cloudiness: clear days (0-2/10 of cloud cover at Staré Město), cloudy days (2.1-7.9/10 of cloud cover at Staré Město, sum of categories 2, 3, and 4 at Buchlovice see Fig. 7), and overcast days (8-10/10 of cloud cover at Staré Město).

pared to Staré Město overestimates the number of clear days (76.7 to $46.8 \mathrm{~d}$ annually) and underestimates the number of cloudy days (117.5 and $172.3 \mathrm{~d}$, respectively).

\section{Conclusions}

The following conclusions may be drawn from this analysis of the weather diary records kept by Šimon Hausner from Buchlovice in south-eastern Moravia, Czech Republic, in the first third of the 19th century:

i. The Hausner's weather diary is a valuable source of meteorological and weather-related information from south-eastern Moravia in the 1803-1830 period. It enables the creation of a representative series of selected characteristics of temperature, precipitation, cloudiness, wind, other meteorological phenomena, and weatherrelated phenological events and agricultural work. ii. Interpretation of Hausner's weather observations also enables the creation of series of weighted temperature and precipitation indices for south-eastern Moravia, which may then be used in the overlap period with the early instrumental meteorological observations in the Czech Republic for a calibration or verification exercise in temperature and precipitation reconstructions that combine documentary and instrumental data.

iii. Series of 7-degree weighted temperature and precipitation indices derived from Hausner's weather diary describe highly representative climate fluctuations in south-eastern Moravia during the 1803-1830 period. The cold period in 1812-1816 and the dry period of $1805-1811$ are particularly worthy of note.

iv. Hausner's data have great meteorological, climatological, and phenological validity and significantly supplement the Czech database of historical-climatological 
data and extend knowledge of climatic variability of the first third of the 19th century in central Europe.

Data availability. The original daily weather records of $\breve{S}$ imon Hausner are available in the Moravian Land Archives, Brno, fund G 138, catalogue no. 851. Data used in graphs are available from the corresponding author.

Author contributions. RB designed the paper and carried out meteorological interpretation of Hausner's observations. HV extracted weather records from archives. $\mathrm{KC}$ created a database with part contribution by AV and created various graphs for selected variables. LD collected data of Hausner's biography and worked on the translation of original records, similarly as MB. Ľ̌ was involved in work with indices and the creation of several figures. PZ contributed with recent meteorological data for the 1961-1990 period.

Competing interests. The authors declare that they have no conflict of interest.

Acknowledgements. The study was supported by the Ministry of Education, Youths and Sport of the Czech Republic for the SustES - Adaptation strategies for sustainable ecosystem services and food security under adverse environmental conditions, project no. CZ.02.1.01/0.0/0.0/16_019/0000797. Tony Long (Svinošice) helped work up the English.

Financial support. This research has been supported by the Ministry of Education, Youths and Sport of the Czech Republic (grant no. CZ.02.1.01/0.0/0.0/16_019/0000797).

Review statement. This paper was edited by Chantal Camenisch and reviewed by two anonymous referees.

\section{Archival sources}

[AS1] Moravský zemský archiv Brno, fond B 16 Děkanské matriky uherskohradišťského děkanátu, Kniha 416 Uherské Hradiště 18041808.

[AS2] Moravský zemský archiv Brno, fond G 138 Rodinný archiv Berchtoldů (1202)1494-1945, inv. č. 349 Spory - s osvětimanským farářem Šimonem Hausnerem, 1825.

[AS3] Moravský zemský archiv Brno, fond G 138 Rodinný archiv Berchtoldů (1202)1494-1945, inv. č. 851 Denní sledování počasí buchlovským farářem Šimonem Hausnerem 1803-1831.

[AS4] Moravský zemský archiv Brno, fond F 45 Velkostatek Buchlov (1514)1548-1949, inv. č. 449 Živelní škody, 1797-1848.

[AS5] Moravský zemský archiv Brno, fond G 82 Hospodářská společnost Brno 1769-1937, sign. IV/3e Meteorologická pozorování (cartons 204-206).

\section{References}

Adamson, G. C. D.: Private diaries as information sources in climate research, WIREs Clim. Change, 6, 599-611, https://doi.org/10.1002/wcc.365, 2015.

Adamson, G. C. D. and Nash, D. J.: Documentary reconstruction of monsoon rainfall variability over western India, 1781-1860, Clim. Dynam., 42, 749-769, https://doi.org/10.1007/s00382013-1825-6, 2014.

Bokwa, A., Limanówka, D., and Wibig, J.: Pre-instrumental weather observations in Poland in the 16th and 17th centuries, in: History and Climate. Memories of the Future?, edited by: Jones, P. D., Ogilvie, A. E. J., Davies, T. D., and Briffa, K. R., Kluwer Academic/Plenum Publishers, New York, Boston, Dordrecht, London, Moscow, 9-27, 2001.

Brázdil, R. and Kiss, A.: Daily weather observations at Košice, Slovakia, in the period 1677-1681, Meteorol. Čas., 4, 3-14, 2001.

Brázdil, R. and Kotyza, O.: Daily meteorological observations of Charles Senior of Žerotín in the years 1588-1591, Scripta Fac. Sci. Nat. Univ. Masarykianae Brunensis (Geographia), 25, 7-39, 1995.

Brázdil, R. and Kotyza, O.: History of Weather and Climate in the Czech Lands II. The Earliest Daily Observations of the Weather in the Czech Lands, Masaryk University, Brno, 1996.

Brázdil, R. and Valášek, H.: Popis klimatu Moravy od Kryštofa Passyho z roku 1797 (The description of the climate of Moravia by Kryštof Passy from the year 1797), Geografie, 106, 234-250, 2001.

Brázdil, R., Valášek, H., and Macková, J.: Meteorologická pozorování P. Tadeáše Štiky v Počaplech z let 1788-1789 (Meteorological observations of parson Tadeáš Štika at Počaply in 1788-1789), Meteorol. Zpr., 55, 151-157, 2002a.

Brázdil, R., Valášek, H., Sviták, Z., and Macková, J.: History of Weather and Climate in the Czech Lands V. Instrumental Meteorological Measurements in Moravia up to the End of the Eighteenth Century, Masaryk University, Brno, 2002b.

Brázdil, R., Valášek, H., and Macková, J.: Climate in the Czech Lands during the 1780s in light of the daily weather records of parson Karel Bernard Hein of Hodonice (south-western Moravia): Comparison of documentary and instrumental data, Climatic Change, 60, 297-327, https://doi.org/10.1023/A:1026045902062, 2003.

Brázdil, R., Pfister, C., Wanner, H., von Storch, H., and Luterbacher, J.: Historical climatology in Europe - the state of the art, Climatic Change, 70, 363-430, https://doi.org/10.1007/s10584-005-59241, 2005a.

Brázdil, R., Valášek, H., and Macková, J.: Meteorologická pozorování v Brně v první polovině 19. století. Historie počasí a hydrometeorologických extrémů (Meteorological Observations in Brno in the First Half of the Nineteenth Century. History of Weather and Hydrometeorological Extremes), Archiv města Brna, Brno, 2005b.

Brázdil, R., Řezníčková, L., and Valášek, H.: Early instrumental meteorological observations in the Czech Lands I: Ferdinand Knittelmayer, Brno, 1799-1812, Meteorol. Čas., 9, 59-71, 2006.

Brázdil, R., Řezníčková, L., and Valášek, H.: Early instrumental meteorological observations in the Czech Lands II: Andreas Sterly, Jihlava, 1816-1840 (1844), Meteorol. Čas., 10, 3-12, 2007a. 
Brázdil, R., Řezníčková, L., and Valášek, H.: Počasí v Čechách v letech 1805-1806: konfrontace vizuálních a přístrojových pozorování (Weather in Bohemia in 1805-1806: comparison of visual and instrumental observations), Meteorol. Zpr., 60, 187193, 2007b.

Brázdil, R., Černušák, T., and Řezníčková, L.: Weather information in the diaries of the Premonstratensian Abbey at Hradisko, in the Czech Republic, 1693-1783, Weather, 63, 201-207, https://doi.org/10.1002/wea.264, 2008a.

Brázdil, R., Kiss, A., Luterbacher, J., and Valášek, H.: Weather patterns in eastern Slovakia 1717-1730, based on records from Breslau meteorological network, Int. J. Climatol., 28, 16391651, https://doi.org/10.1002/joc.1667, 2008b.

Brázdil, R., Dobrovolný, P., Luterbacher, J., Moberg, A., Pfister, C., Wheeler, D., and Zorita, E.: European climate of the past 500 years: new challenges for historical climatology, Climatic Change, 101, 7-40, https://doi.org/10.1007/s10584-009-9783-z, 2010.

Brázdil, R., Černušák, T., and Řezníčková, L.: The Weather and Climate in the Region of Olomouc, Czech Republic, Based on Premonstratensian Diaries Kept by the Hradisko Monastery and Svatý Kopeček Priory, 1693-1783, Masaryk University, Brno, 2011.

Brázdil, R., Bělínová, M., Dobrovolný, P., Mikšovský, J., Pišoft, P., Řezníčková, L., Štěpánek, P., Valášek, H., and Zahradníček, P.: Temperature and Precipitation Fluctuations in the Czech Lands During the Instrumental Period, Masaryk University, Brno, 2012a.

Brázdil, R., Chromá, K., Valášek, H., and Dolák, L.: Hydrometeorological extremes derived from taxation records for south-eastern Moravia, Czech Republic, 1751-1900 AD, Clim. Past, 8, 467481, https://doi.org/10.5194/cp-8-467-2012, $2012 b$.

Brázdil, R., Kotyza, O., Dobrovolný, P., Řezníčková, L., and Valášek, H.: Climate of the Sixteenth Century in the Czech Lands, Masaryk University, Brno, 2013a.

Brázdil, R., Řezníčková, L., and Valášek, H.: Meteorologická pozorování Alexandra Zawadzkého v Brně v letech 1861-1867 (The meteorological observations made by Alexander Zawadzki in Brno, 1861-1867), Geografie, 118, 334-355, 2013b.

Brázdil, R., Valášek, H., Kašičková, L., and Chromá, K.: Meteorologická pozorování Josefa Lukotky ve Vsetíně v letech $1903-$ 1923 (Meteorological observations made by Josef Lukotka in the town of Vsetín through the years 1903-1923), Meteorol. Zpr., 67, 120-128, 2014.

Chernavskaya, M.: The climate of the Russian plain according to the diary of Peter the Great, and the weather records of Czar Aleksey's court, in: Climatic Trends and Anomalies in Europe 1675-1715. High-resolution Spatio-temporal Reconstructions from Direct Meteorological Observations and Proxy Data. Methods and Results, edited by: Frenzel, B., Pfister, C., and Gläser, B., Gustav Fischer Verlag, Stuttgart, Jena, New York, 7381, 1994.

Domínguez-Castro, F., García-Herrera, R., and Vaquero, J. M.: An early weather diary from Iberia (Lisbon, 1631-1632), Weather, 70, 20-24, https://doi.org/10.1002/wea.2319, 2015.

Druckenbrod, D. L., Mann, M. E., Stahle, D. W., Cleaveland, M. K., Therrell, M. D., and Shugart, H. H.: Late-eighteenthcentury precipitation reconstructions from James Madison's
Montpelier plantation, B. Am. Meteorol. Soc., 84, 57-71, https://doi.org/10.1175/BAMS-84-1-57, 2003.

Fernández-Fernández, M. I., Gallego, M. C., Domínguez-Castro, F., Trigo, R. M., and Vaquero, J. M.: The climate in Zafra from 1750 to 1840: temperature indices from documentary sources, Climatic Change, 141, 671-684, https://doi.org/10.1007/s10584017-1910-7, 2017.

Filipiak, J., Przybylak, R., and Oliński, P.: The longest oneman weather chronicle (1721-1786) by Gottfried Reyger for Gdańsk, Poland as a source for improved understanding of past climate variability, Int. J. Climatol., 39, 828-842, https://doi.org/10.1002/joc.5845, 2019.

Glaser, R., Militzer, S., and Walsh, R.: Weather and climate at Madras, India, in the years 1732-1737 based upon an analysis of the weather diary of the German missionary Geisler, Würzburger Geographische Arbeiten, 80, 45-86, 1991.

Hirano, J. and Mikami, T.: Reconstruction of winter climate variations during the 19th century in Japan, Int. J. Climatol., 28, 14231434, https://doi.org/10.1002/joc.1632, 2008.

Hrdý, M., Kořínek, V., and Žižlavský, B.: Moje Buchlovice: 200 let městečka: 20.5.1805-20.5.2005 (My Buchlovice: 200 Years of a Small Town: 20 May 1805-20 May 2005), Obec Buchlovice, Buchlovice, 2005.

Lawrence, E. N.: The earliest known journal of the weather, Weather, 27, 494-501, 1972.

Lee, D. S. and MacKenzie, A. R.: Trans-hemispheric effects of large volcanic eruptions as recorded by an early 19 th century diary, Int. J. Climatol., 30, 2217-2228, https://doi.org/10.1002/joc.2034, 2010.

Lenke, W.: Das Klima Ende des 16. und Anfang des 17. Jahrhunderts nach Beobachtungen von Tycho Brahe auf Hven, Leonhard III Treuttwein in Fürstenfeld und David Fabricius in Ostfriesland, Ber. Deutsch. Wetterd. 110, Offenbach a. M., 1968.

Limanówka, D.: Rekonstrukcja warunków klimatycznych Krakowa w pierwszej połowie XVI wieku (Reconstruction of Climatic Patterns in Cracow in the First Half of the 16th Century), Materiały Badawcze, Seria: Meteorologia - 33, Instytut Meteorologii i Gospodarki Wodnej, Warszawa, 2001.

Long, C.: The oldest European weather diary?, Weather, 29, 233 237, 1974.

Lorrey, A. M. and Chappell, P. R.: The "dirty weather" diaries of Reverend Richard Davis: insights about early colonial-era meteorology and climate variability for northern New Zealand, 18391851, Clim. Past, 12, 553-573, https://doi.org/10.5194/cp-12553-2016, 2016.

Luterbacher, J. and Pfister, C.: The year without a summer, Nat. Geosci., 8, 246-248, https://doi.org/10.1038/ngeo2404, 2015.

Metzger, A. and Tabeaud, M.: Reconstruction of the winter weather in east Friesland at the turn of the sixteenth and seventeenth centuries (1594-1612), Climatic Change, 141, 331-345, https://doi.org/10.1007/s10584-017-1903-6, 2017.

Mikami, T.: Climatic variations in Japan reconstructed from historical documents, Weather, 63, 190-193, https://doi.org/10.1002/wea.281, 2008.

Munzar, J.: Floods in Central Europe after the exceedingly severe winter season 1829/1830, Moravian Geogr. Rep., 8, 46-57, 2000.

Munzar, J. and Kakos, V.: Zima 1829/30 - nejtužší ve střední Evropě od počátku měřní teploty vzduchu (The winter of 
$1829 / 1830$ - the most severe in central Europe since air temperature measurements began), Meteorol. Zpr., 53, 103-108, 2000.

Nowosad, W., Przybylak, R., Marciniak, K., and Syta, K.: Diariusz Jan Antoniego Chrapowickiego jako źródlo do badań klimatu Rzezcypospolitej w drugiej połowie XVII wieku (The diary of Jan Antoni Chrapowicki as a source for researchers on climate of Poland in the second half of the 17th century), Klio, 9, 21-60, 2007.

Pejml, K.: 200 let meteorologické observatoře v pražském Klementinu (Two Hundred Years of the Prague-Klementinum Meteorological Observatory), Hydrometeorologický ústav, Praha, 1975.

Pfister, C.: Monthly temperature and precipitation in central Europe 1525-1979: quantifying documentary evidence on weather and its effects, in: Climate Since A.D. 1500, edited by: Bradley, R. S. and Jones, P. D., Routledge, London, New York, 118-142, 1992.

Pfister, C., Brázdil, R., Glaser, R., Bokwa, A., Holawe, F., Limanowka, D., Kotyza, O., Munzar, J., Rácz, L., Strömmer, E., and Schwarz-Zanetti, G.: Daily weather observations in sixteenth-century Europe, Climatic Change, 43, 111-150, https://doi.org/10.1023/A:1005505113244, 1999.

Przybylak, R. and Marciniak, K.: Climate changes in the central and north-eastern parts of the Polish-Lithuanian commonwealth from 1656 to 1685, in: The Polish Climate in the European Context: An Historical Overview, edited by: Przybylak, R., Majorowicz, J., Brázdil, R., and Kejna, M., Springer Science + Business Media B. V., Dordrecht, Heidelberg, London, New York, 423-443, 2010 .
Raicich, F.: Some features of Trieste climate from an eighteenth century diary (1732-1749), Climatic Change, 86, 211-226, https://doi.org/10.1007/s10584-007-9357-x, 2008.

Sanderson, M. G.: Daily weather in Dublin 1716-1734: the diary of Isaac Butler, Weather, 73, 179-182, https://doi.org/10.1002/wea.3029, 2018.

White, S., Pfister, C., and Mauelshagen, F. (Eds.): The Palgrave Handbook of Climate History, Palgrave Macmillan, London, 2018.

WMO: WMO Guidelines on the Calculation of Climate Normals, WMO-No. 1203, World Meteorological Organization, Geneva, 2017.

Woodworth, P. M.: The meteorological data of William Hutchinson and a Liverpool air pressure time series spanning 1768-1999, Int. J. Climatol., 26, 1713-1726, https://doi.org/10.1002/joc.1335, 2006.

Zhang, X.-Z., Ge, Q.-S., Fang, X.-Q., Zheng, J.-Y., and Fei, J.: Precipitation variations in Beijing during 1860-1897 AD revealed by daily weather records from the Weng Tong-He Diary, Int. J. Climatol., 33, 568-576, https://doi.org/10.1002/joc.3448, 2013.

Žižlavský, B.: Písmák a kněz Šimon Hausner (The chronicler and reverend Šimon Hausner), Malovaný kraj, 34, 14-15, 1998.

Zwitter, Ž.: Vremenska in klimatska zgodovina v koledarjih in podložniških dnevnikih ljubljanskega škofa Tomaža Hrena (15971630) (History of weather and climate in calendars and manorial minutes of Tomaž Hren, Bishop of Ljubljana (1597-1630)), Zgodovinski Čas., 67, 306-389, 2013. 